\title{
Cyberbullying in elementary and middle school students: A systematic review
}

\author{
Carlos Evangelio a , Pablo Rodríguez-González ${ }^{\mathrm{b}}$, Javier Fernández-Río ${ }^{\mathrm{b}, *}$, \\ Sixto Gonzalez-Villora ${ }^{\text {a }}$ \\ ${ }^{a}$ Departamento de Didáctica de la Expresión Musical, Plástica y Corporal, Facultad de Educación, Universidad de Castilla-La Mancha, Campus \\ Universitario $s / n$, Cuenca, 16071, Spain \\ ${ }^{\mathrm{b}}$ Departamento de Ciencias de la Educación, Facultad de Formación del Profesorado y Educación, Universidad de Oviedo, Aniceto Sela s/n, Oviedo, \\ 33005, Spain
}

\section{A R T I C L E I N F O}

\section{Keywords:}

Children

Cybervictim

Cyberwitness

Early school years

\begin{abstract}
A B S T R A C T
The goal of the present study was to extend the scope of previous reviews on cyberbullying to focus on elementary and middle school students, ages when research indicates that children begin to use mobile phones and social media. From 2016 to 2020, a total of 43 articles were included in the final selection, and purpose/s, sample, design/instruments, and main findings/conclusions were assessed on each one. The following topics emerged from the results and were discussed: cyberbullying/cybervictimization and psychosocial variables, students' sociodemographic variables, connections between bullying and cyberbullying, students' roles related to cyberbullying, external factors and students' responses, and effectiveness of cyberbullying programs. Students experiencing cyberbullying at an early school age reported negative feelings, such as depression or anxiety. They are often linked to bullying scenarios and even to the same role (cyberbully, cybervictim or cyberwitness). Different programs have been shown to positively influence cyberbullying from a young age, important to prevent it, when children begin to use mobile phones and social media. Protective factors, such as specific pedagogical approaches (e.g. Cooperative Learning or Teaching for Personal and Social Responsibility) or programs, as well as the joined work of different agents (e.g. psychologists, teachers, parents, peers), should be considered to promote a positive evolution on CB prevention. Nevertheless, more studies are needed at these grades, as well as qualitative research designs, to deepen on the students' feelings on cyberbullying.
\end{abstract}

\section{Introduction}

Today's social networks and instant messaging applications have become everyday virtual platforms in our society. Given the constant availability of computer devices for children and adolescents (e.g., cell phones, computers, tablets) and the possibility of being constantly connected with the rest of the world, new types of social relationships and behaviors are emerging and developing (Hüiür \& Macdonald, 2020). The use of social networks offers great opportunities to connect with others, giving birth to online communities where you can meet people with similar interests or maintain relationships with others (Ellison, Steinfield, \& Lampe,

\footnotetext{
* Corresponding author.

E-mail addresses: carlos.evangelio@uclm.es (C. Evangelio), UO259187@uniovi.es (P. Rodríguez-González), javier.rio@uniovi.es (J. FernándezRío), sixto.gonzalez@uclm.es (S. Gonzalez-Villora).
} 
2007). Half of ten-year-olds have their own smartphone, being between the ages of nine and ten when smartphone ownership doubles, "marking an important milestone in children's digital independence as they prepare for secondary school" (Ofcom, 2020, p.1). However, the use of social networks presents risks for those involved, especially for children and adolescents, and cyberbullying (CB) is one of them (Aizenkot, 2017; Patchin \& Hinduja, 2015). The current context is so problematic that it has been declared a global issue occurring at different educational stages (Kowalski, Giumetti, Schroeder, \& Lattanner, 2014).

CB is a form of bullying that reaches all ages due to the ubiquity and anonymity of social networks (Peter \& Petermann, 2018). Mockery and derision haunt many students (Kowalski, Limber, \& McCord, 2019; Patchin \& Hinduja, 2010). Although according to prior evidence traditional bullying and CB seem to be correlated (Görzig \& Machackova, 2015), there is still some debate as to whether $\mathrm{CB}$ is a distinct form of bullying or simply bullying using electronic platforms. Traditional bullying is typically defined as an act of aggression that is repeated over time and that is intended to cause harm or distress among individuals whose relationship is characterized by a power imbalance (Olweus, 1993; 2013). Thus, the definition of bullying is based on three fundamental characteristics: intent to harm, repetition, and an imbalance of power between the victim and the perpetrator (Olweus, 1997). Despite sharing some characteristics, traditional bullying and CB differ in important features that influence outcomes experienced by CB and traditional bullying victims (Giumetti \& Kowalski, 2016). Similar definitions have been offered for CB based on the three key characteristics noted for the traditional forms of bullying (Slonje \& Smith, 2010; Olweus \& Limber, 2018). However, there is some debate about how each traditional bullying characteristic applies to CB (Olweus, 2013). The digital medium includes specific features: (a) wider audience and impact, which enhances its negative effects; (b) anonymity, which makes it easier to be both a cyberbully and a victim; (c) permanence, bullying acts remain "active" longer; and (d) minimal restrictions, there is hardly any control (Nocentini et al., 2010; Smith \& Slonje, 2010). Due to the lack of agreement on the definition and the basic elements, other terms have emerged: internet harassment, online harassment, and online bullying, making it difficult to differentiate between them (Menesini, Nocentini, Palladino, Frisén, Berne, Ortega-Ruiz et al., 2012).

Nevertheless, Tokunaga's (2010) definition of CB seems to be the most widely accepted: "Cyberbullying is any behavior performed through electronic or digital media by individuals or groups that repeatedly communicates hostile or aggressive messages intended to inflict harm or discomfort on others" (p. 278). This definition does not include a power differential, which is a central feature of traditional bullying. Furthermore, it is not clear whether it is possible to see the power imbalance and repetitiveness characteristics of traditional bullying in CB (Olweus, 2013). Smith, del Barrio and Tokunaga (2013) explained that power imbalance with electronic means could be understood in terms of differences in technological expertise between the aggressor and the victim, relative anonymity, social status, number of friends or marginalized group position. The repetitiveness feature in CB could also be understood as the way in which negative messages, images or videos reach individuals; or the time that these messages, images or videos last in the net, more than on the cyberbully's behavior, which is often a single act (Olweus \& Limber, 2018). CB includes, among others, attitudes and actions such as excluding someone from an online group, spreading gossip by mobile phone, making threatening, abusive or offensive remarks on social networks, sending WhatsApp messages to insult or threaten, or uploading degrading videos on online platforms (Garaigordobil, 2015).

CB perpetration, cybervictimization (CV) and $\mathrm{CB}$ witnessing (CBW) have been associated with adverse physical, psychosocial and/ or educational expectations (Kowalski et al., 2014). According to prior evidence, some individuals who got involved in CB as victims reported low self-esteem (Palermiti, Servidio, Bartolo, \& Costabile, 2017; Patchin \& Hinduja, 2010; Wachs, Vazsonyi, Wright, \& Ksinan Jiskrova, 2020), stress (Garaigordobil \& Machimbarrena, 2019; Martínez-Monteagudo, Delgado, Díaz-Herrero, \& García-Fernández, 2020), anxiety (Chu, Fan, Liu, \& Zhou, 2018a; Martínez-Monteagudo et al., 2020), depression (Calvete, Orue, \& Gámez-Guadix, 2016; Chu et al., 2018a; Varghese \& Pistole, 2017), low academic performance (Torres, D'Alessio, \& Stolzenberg, 2020) and suicidal ideations (Kowalski et al., 2014). For its part, some cyberbullies showed aggressive behavior (Fletcher et al., 2014), low self-esteem (Patchin \& Hinduja, 2010), stress (Cañas, Estévez, Marzo, \& Piqueras, 2019), anxiety (Pabian \& Vandebosch, 2016) and depression (Cañas et al., 2019; Wang et al., 2019). Some witnesses of CB showed depression and anxiety (Wright, Wachs, \& Harper, 2018) and some who did not become involved while witnessing CB aggressions, experienced depression and suicidal ideation (DeSmet, De Bourdeaudhuij, Walrave, \& Vandebosch, 2019). DeSmet et al. (2019) found no significant adverse psychological problems in those cyberwitnessess who got involved while CB occurred.

Regardless of the role played in CB, previous systematic reviews on CB (e.g., Camerini, Marciano, Carrara, \& Schulz, 2020; Kowalski et al., 2014; Zych, Ortega-Ruiz, \& Del Rey, 2015; Zych, Ortega-Ruiz, \& Marín-López, 2016) acknowledged the impact on different psychological variables, the influence of socio-demographic variables (e.g., gender, age), the relation between $\mathrm{CB}$ and traditional bullying (Jadambaa et al., 2019), the effects of several anti-bullying interventions conducted (Tanrikulu, 2018) or the causal and environmental factors influencing CB (Heerde \& Hemphill, 2018). These previous reviews assessed primary, middle and high school students (e.g., Zych et al., 2016) or middle and high school students (e.g., Heerde \& Hemphill, 2018) jointly, making it hard to understand, precisely, and draw conclusions on primary and middle school students, when research indicates that children begin to use mobile phones and social media. Consequently, there seems to exist a gap of systematic reviews on CB focused on primary education and middle school.

International reports on internet use showed an increase in elementary and middle school students: $99 \%$ of children aged 12-15 in the United Kingdom (Ofcom, 2017), 86.7\% of children aged 10 and 93\% aged 13 in Spain (National Statistics Institute, 2019), and similar data for the United States (Pew Research Center, 2018). Previous studies reported grades 5-6 as the beginning of children's access to technology and CB (Cole et al., 2016; Holfeld \& Leadbeater, 2015), and Aizenkot and Kashy-Rosenbaum (2019) concluded that CV was more likely in grades 4-6 than in older graders. Furthermore, middle school (grades 6-8) seems to be the time when CB peaks, continuing through high school, college, and work (Kowalski et al., 2014; Myers \& Cowie, 2019; Tokunaga, 2010). For these reasons (the lack of a specific review on elementary/middle school and the relevance of internet and social media use from short ages), 
specific information is still needed to understand the impact of CB on elementary and middle school students to help prevent it in these and subsequent ages, as well as to uncover protective factors (Hamm et al., 2015; Zych et al., 2015).

\section{Research aims}

Based on the aforementioned, and on the ideas uncovered in previous studies, the aim of this review was to assess CB in young graders, identifying existing empirical studies conducted in elementary and middle school students (Grades 1-8) from 2016 to 2020 to highlight the importance of these ages in the prevention of $\mathrm{CB}$ behaviors. Two research questions guided this study (1) What are the characteristics of the studies (e.g., purposes, samples, research designs): conducted in elementary and middle school students on $\mathrm{CB}$ and their differences with other studies in older ages over the last five years?; (2) What specifically happens in elementary and middle school students and what is the relation between the findings/conclusions and the main issues identified in previous reviews conducted in middle and high school students?

To answer the first question, the articles selected were analyzed based on: 'authors' (publication year); 'purpose/s'; 'sample'; 'design/instruments'; 'main findings/conclusions (theme/s of the thematic analysis)'. To answer the second question, the findings and conclusions of the selected articles were categorized using inductive thematic analysis. The results of this review were discussed comparing them with findings from previous studies in the same section (4. Results and discussion) to facilitate their understanding.

\section{Flow diagram of the systematic search.}

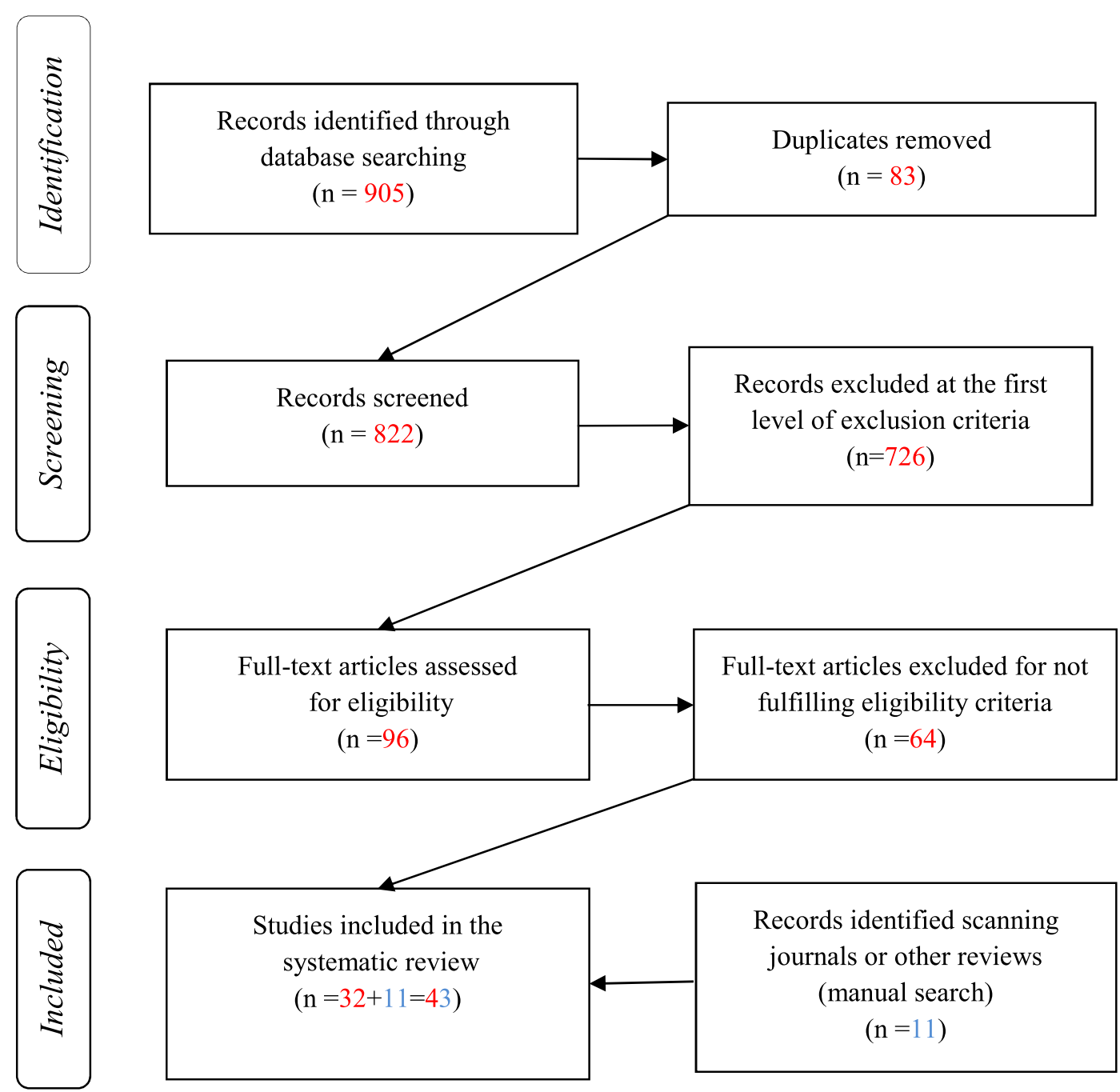

Fig. 1. Flow diagram of the systematic search. 
Table 1

MMAT to assess the studies quality (Hong et al., 2018).

Qualitative studies

Author/s (year)

\begin{tabular}{llllllllll} 
& & \multicolumn{1}{c}{ Randomized controlled trials } \\
1.1. & 1.2. & 1.3. & 1.4. & 1.5. & 2.1 & 2.2 & 2.3 & 2.4 & 2.5
\end{tabular}

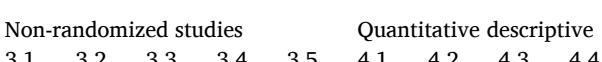

Aizenkot and Kashy-Rosenbaum (2018)

ashy-Rosenbaum (2020)

Athanasiades et al. (2016)

Carter et al. (2020)

Coelho and Romão (2018)

Cole et al. (2016)

Cuesta, Hennig, Adriana \& Malfasi (2020)

Da Silva et al. (2016)

Delgado, Escortell, Martínez-Monteagudo, Ferrández \& Sanmartín

$$
\text { (2019) }
$$

Delgado and Escortell (2018)

DeSmet et al. (2018)

Díaz and Fite (2019)

Doumas and Midgett (2020)

Escortell, Aparisi, et al. (2020)

Escortell, Delgado, and Martínez-Monteagudo (2020)

Fahy et al. (2016)

Garaigordobil and Martínez-Valderrey (2016)

Gradinger et al. (2016)

Govender and Young (2018)

Holfeld and Leadbeater (2017)

Knauf et al. (2018)

Longobardi, Gullotta, Ferrigno, Jungert, Thonberg \& Settann

$$
\text { (2020) }
$$

López-Pradas et al. (2017)

Machimbarrena and Garaigordobil (2017)

Machimbarrena \& Garaigordobil (2018a)

Meter and Bauman (2018)

Moyano et al. (2019)

Muller et al. (2017)

Navarro et al. (2018)

Quintana-Orts and Rey (2018)

Sidera et al. (2020)

Solomontos-Kountouri et al. (2016)

Vivolo-Kantor et al. (2020)

Wang et al. (2019)

Wegge et al. (2016)

Wright (2016)

Wright (2017a)

Wright (2017b)

Wright (2017c)

Wright and Wachs (2019)

Wright and Wachs (2020)

Zhang et al. (2020)

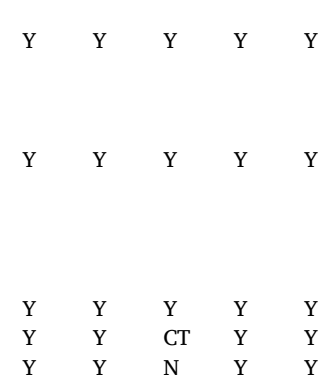

$\begin{array}{lllll}\mathrm{Y} & \mathrm{Y} & \mathrm{Y} & \mathrm{Y} & \mathrm{Y} \\ \mathrm{Y} & \mathrm{Y} & \mathrm{Y} & \mathrm{Y} & \mathrm{Y} \\ \mathrm{Y} & \mathrm{Y} & \mathrm{Y} & \mathrm{Y} & \mathrm{Y} \\ \mathrm{Y} & \mathrm{Y} & \mathrm{Y} & \mathrm{Y} & \mathrm{Y} \\ \mathrm{Y} & \mathrm{Y} & \mathrm{Y} & \mathrm{Y} & \mathrm{Y} \\ \mathrm{Y} & \mathrm{Y} & \mathrm{Y} & \mathrm{Y} & \mathrm{Y}\end{array}$

.

For each item: Yes $(\mathrm{Y})=1$; No $(\mathrm{N})=0$; Cannot tell $(\mathrm{CT})=0.5$. Quality rating $(\mathrm{QR})$ : Low $(\mathrm{L})=1-2 ;$ Medium $(\mathrm{M})=3$; High $(\mathrm{H})=4-5$.

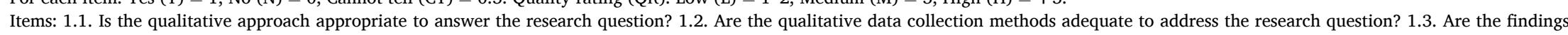

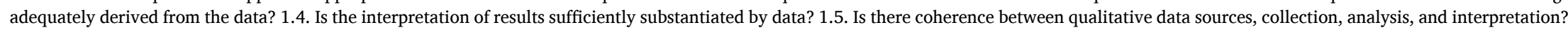

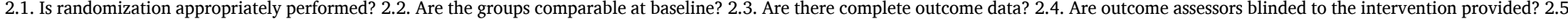

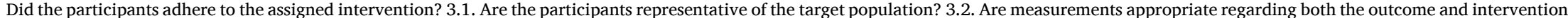

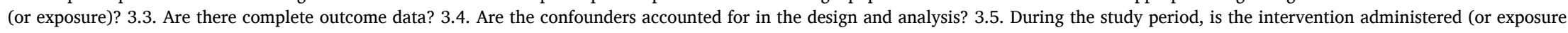

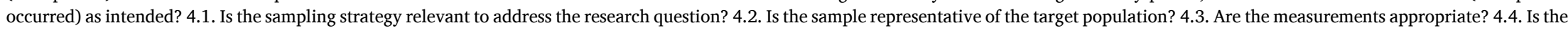
risk of nonresponse bias low? 4.5. Is the statistical analysis appropriate to answer the research question?. 
Table 2

Summary of studies selected from the systematic review.

\begin{tabular}{|c|c|c|c|c|}
\hline Authors (year) & Purpose/s & Sample & Design/instruments & $\begin{array}{l}\text { Findings/conclusions } \\
\text { (theme/s) }\end{array}$ \\
\hline $\begin{array}{l}\text { Aizenkot and Kashy-Rosenbaum } \\
\text { (2018) }\end{array}$ & $\begin{array}{l}\text { Evaluate the effectiveness of } \\
\text { an intervention program } \\
\text { designed to reduce CB and } \\
\text { improve usage of WhatsApp } \\
\text { classmates' groups. }\end{array}$ & $\begin{array}{l}1268 \text { 4th-6th and 8th } \\
\text { graders ( } 52 \% \text { female); } \\
12 \text { schools; Israel. }\end{array}$ & $\begin{array}{l}\text { CB in WhatsApp classmates' } \\
\text { group quest.; Usage norms of } \\
\text { WhatsApp classmates' groups; } \\
\text { Classroom climate; WhatsApp } \\
\text { classmates' group activity } \\
\text { level. }\end{array}$ & $\begin{array}{l}\text { The intervention led to a } \\
\text { significant improvement of } \\
\text { usage norms in WhatsApp } \\
\text { classmates' groups. } \\
\text { Classroom climate also } \\
\text { improved. (1) }\end{array}$ \\
\hline $\begin{array}{l}\text { Aizenkot and Kashy-Rosenbaum } \\
\quad \text { (2020) }\end{array}$ & $\begin{array}{l}\text { Explore the results of the } \\
\text { Safe Surfing program to } \\
\text { decrease CB in WhatsApp } \\
\text { classmate discourse. }\end{array}$ & $\begin{array}{l}5334 \text { th-6th graders } \\
\text { (50\% female); } 6 \text { schools; } \\
\text { Israel. }\end{array}$ & $\begin{array}{l}\text { CV in WhatsApp classmate } \\
\text { discourse quest.; Perception of } \\
\text { classroom climate and student } \\
\text { sense of class belonging quest. } \\
\text { (RAMA, 2015). }\end{array}$ & $\begin{array}{l}\text { Students decreased their } \\
\text { CV in WhatsApp, } \\
\text { improving the classroom } \\
\text { climate and their sense of } \\
\text { class belonging. (1) }\end{array}$ \\
\hline Athanasiades et al. (2016) & $\begin{array}{l}\text { Assess the effects of Internet } \\
\text { use, parental mediation, } \\
\text { victimization, gender, } \\
\text { bullying and empathy on CB } \\
\text { and CV ( } 2 \text { measures/4 } \\
\text { months). }\end{array}$ & $\begin{array}{l}440 \text { 7th-8th graders } \\
\left(46.1 \% \text { female; } M_{a g e}=\right. \\
\text { 12.74); } 6 \text { schools; } \\
\text { Greece. }\end{array}$ & $\begin{array}{l}\text { Self-reported quest. to assess } \\
\text { demographic features, use of } \\
\text { social networks, students' } \\
\text { involvement in bullying and } \\
\text { CB incident, and students' } \\
\text { knowledge of the CB. }\end{array}$ & $\begin{array}{l}\text { Involvement in traditional } \\
\text { bullying as a victim or } \\
\text { perpetrator is the factor } \\
\text { with the highest } \\
\text { predictability of CB and CV. } \\
(2,3,5)\end{array}$ \\
\hline Carter et al. (2020) & $\begin{array}{l}\text { Study the mediation/ } \\
\text { moderation of the parent- } \\
\text { child attachment students' } \\
\text { perception on the links } \\
\text { between parenting } \\
\text { dimensions and different } \\
\text { types of bullying. }\end{array}$ & $\begin{array}{l}10785 \text { th-6th graders } \\
\left(59.1 \% \text { female; } \mathrm{M}_{\mathrm{age}}=\right. \\
11.24) \text {; South Africa. }\end{array}$ & $\begin{array}{l}\text { Inventory of Parent and Peer } \\
\text { Attachment Revised (Gullone } \\
\text { \& Robinson, 2005); } \\
\text { Adolescent Peer Relations: } \\
\text { Bully/Target (Parada, 2000); } \\
\text { Child's Report of Parental } \\
\text { Behaviour Inventory } 30 \\
\text { (Schaefer, 1965). }\end{array}$ & $\begin{array}{l}\text { Parent-child attachment } \\
\text { mediated the relations } \\
\text { between parental } \\
\text { acceptance-bullying events } \\
\text { and moderate the first- } \\
\text { verbal bullying. CB was } \\
\text { lower than other forms of } \\
\text { bullying. }(4,5)\end{array}$ \\
\hline Chu et al. (2018b) & $\begin{array}{l}\text { Examine whether bullies and } \\
\text { victims would remain or } \\
\text { change their roles across } \\
\text { time in traditional and } \\
\text { virtual contexts. }\end{array}$ & $\begin{array}{l}6617 \text { th-8th graders } \\
\text { (39\% female; } 11-15 \\
\text { years); China. }\end{array}$ & $\begin{array}{l}\text { Traditional Bullying Scale (Li } \\
\text { et al., 2012); Chinese version } \\
\text { of the Revised CB Inventory } \\
\text { (Topcu \& Erdur-Baker, 2010); } \\
\text { CB Victimization (Chu \& Fan, } \\
\text { 2017). }\end{array}$ & $\begin{array}{l}\text { Bullying roles were } \\
\text { maintained. Cyberbullies } \\
\text { were more likely to become } \\
\text { cybervictims, and victims } \\
\text { to. Bullies continued to } \\
\text { bully online and } \\
\text { cybervictims remained to } \\
\text { be bullied. }(2,4)\end{array}$ \\
\hline Coelho and Romão (2018) & $\begin{array}{l}\text { Study how social withdrawal } \\
\text { and social anxiety involve } \\
\text { students in bullying and CB, } \\
\text { and the influence of the } \\
\text { class-levels. }\end{array}$ & $\begin{array}{l}668 \text { 7th-8th graders } \\
\left(44.2 \% \text { female; } \mathrm{M}_{\mathrm{age}}=\right. \\
\text { 12.73); } 5 \text { schools; } \\
\text { Portugal. }\end{array}$ & $\begin{array}{l}\text { Bullying and CB Behaviors } \\
\text { Quest. (Coelho et al., 2016); } \\
\text { Social Withdrawal and Social } \\
\text { Anxiety subscales (Coelho } \\
\text { et al., 2015). }\end{array}$ & $\begin{array}{l}\text { Bullying/CB overlap in } \\
\text { bullies. Bullying roles } \\
\text { showed higher levels of } \\
\text { withdrawal. CB roles affect } \\
\text { social withdrawal/anxiety. } \\
\text { Girls showed more anxiety } \\
\text { than boys, and CB and } \\
\text { bullying victims than bully- } \\
\text { victims. }(2,3,6)\end{array}$ \\
\hline Cole et al. (2016) & $\begin{array}{l}\text { Examine the relation } \\
\text { between CV and depressive } \\
\text { symptoms/negative self- } \\
\text { cognitions. Compare types of } \\
\text { peer victimization for } 12 \text { - } \\
\text { months and age/gender links } \\
\text { to these types. }\end{array}$ & $\begin{array}{l}827 \text { 3rd-6th graders } \\
\left(55.1 \% \text { female; } \mathrm{M}_{\mathrm{age}}=\right. \\
10.90) ; 6 \text { schools; USA. }\end{array}$ & $\begin{array}{l}\text { Reynolds Adolescent } \\
\text { Depression Scale-2 (Reynolds, } \\
\text { 2002); Behind Your Back } \\
\text { protocol/Peer Victimization } \\
\text { Self-Report (Cole et al., 2014); } \\
\text { Children's Automatic } \\
\text { Thoughts (Schniering \& } \\
\text { Rapee, 2002). }\end{array}$ & $\begin{array}{l}\text { CV was related to negative } \\
\text { self-cognitions and } \\
\text { depressive symptoms } \\
\text { development. CV is less } \\
\text { stable and increase slightly } \\
\text { with time. Gender/age } \\
\text { differences emerged for } \\
\text { others victimizations. }(3,6)\end{array}$ \\
\hline Cuesta et al. (2020) & $\begin{array}{l}\text { Check the effect of CB } \\
\text { prevention program which } \\
\text { involve the safe use of social } \\
\text { media and technologies. }\end{array}$ & $\begin{array}{l}151 \text { 5th graders ( } 51 \% \\
\text { female; 9-11 years); } 5 \\
\text { schools; Colombia. }\end{array}$ & $\begin{array}{l}\text { Focus Groups, and students' } \\
\text { forum postings in Edmodo. }\end{array}$ & $\begin{array}{l}\text { Program helped students to } \\
\text { understand CB and face CB } \\
\text { threats: conflict resolution } \\
\text { skills and students' } \\
\text { empowerment was } \\
\text { relevant. (1) }\end{array}$ \\
\hline Authors (year) & Purpose/s & Sample & Design/instruments & $\begin{array}{l}\text { Findings/conclusions } \\
\text { (theme/s) }\end{array}$ \\
\hline Da Silva et al. (2016) & $\begin{array}{l}\text { Verify whether improving } \\
\text { social and emotional skills } \\
\text { can reduce the victimization } \\
\text { of bullying in Brazilian } \\
\text { students. }\end{array}$ & $\begin{array}{l}78 \text { 6th graders } \\
\text { victimized students } \\
\left(\mathrm{M}_{\mathrm{age}}=11.2\right) ; 6 \text { schools; } \\
\text { Brazil. }\end{array}$ & $\begin{array}{l}\text { Aggression and Peer } \\
\text { Victimization Scale (Cunha } \\
\text { et al., 2009); Peer Report } \\
\text { Sociometric scale (Martins, } \\
\text { 2009); Multimedia System of } \\
\text { Social Skills for Children (Del } \\
\text { Prette \& del Prette, 2005). }\end{array}$ & $\begin{array}{l}\text { Before and after the test, } \\
\text { the victimization rate of the } \\
\text { intervention and the } \\
\text { control groups was } \\
\text { significantly reduced. (1) }\end{array}$ \\
\hline Delgado et al. (2019) & $\begin{array}{l}\text { Analyze the value of } \\
\text { academic goals and self- }\end{array}$ & & $\begin{array}{l}\text { Self-Description Quest. I } \\
\text { (Marsh, 1986); Achievement }\end{array}$ & $\begin{array}{l}\text { Social self-concept, } \\
\text { learning goals (both in } \\
\text { (continued on next page) }\end{array}$ \\
\hline
\end{tabular}


Table 2 (continued)

\begin{tabular}{|c|c|c|c|c|}
\hline Authors (year) & Purpose/s & Sample & Design/instruments & $\begin{array}{l}\text { Findings/conclusions } \\
\text { (theme/s) }\end{array}$ \\
\hline & $\begin{array}{l}\text { concept in cyber bullies, } \\
\text { victims and witnesses in } \\
\text { relation to the gender and } \\
\text { grade. }\end{array}$ & $\begin{array}{l}548 \text { 5th-6th graders } \\
\left(49.8 \% \text { female; } M_{a g e}=\right. \\
10.95) ; 6 \text { schools; Spain. }\end{array}$ & $\begin{array}{l}\text { Goals Tendencies Quest. } \\
\text { (Hayamizu \& Weiner, 1991); } \\
\text { Screening for Peer Bullying ( } \\
\text { Garaigordobil, 2013). }\end{array}$ & $\begin{array}{l}\text { victims) and social } \\
\text { reinforcement goals (in } \\
\text { bullies and witnesses) were } \\
\text { relevant in the emergence } \\
\text { of CB. Results varied } \\
\text { according to gender and } \\
\text { grade. }(2,6)\end{array}$ \\
\hline Delgado and Escortell (2018) & $\begin{array}{l}\text { Analyze the differences of } \\
\text { the CB roles (bully, victim } \\
\text { and witness) according to } \\
\text { gender and grade of the } \\
\text { students. }\end{array}$ & $\begin{array}{l}548 \text { 5th-6th graders } \\
\text { (49.8\% female; } M_{\text {age }}= \\
\text { 10.95); } 6 \text { schools; Spain. }\end{array}$ & $\begin{array}{l}\text { Screening for Peer Bullying ( } \\
\text { Garaigordobil, 2013). }\end{array}$ & $\begin{array}{l}\text { Girls are more victimized } \\
\text { than boys for all roles, but } \\
\text { there were no differences } \\
\text { based on grades. } 5 \text { th } \\
\text { graders produced more } \\
\text { blackmails via calls or } \\
\text { messages, while } 6 \text { th } \\
\text { graders were more } \\
\text { victimized by videos, death } \\
\text { threats and blackmails } \\
\text { about unveiling secrets. } \\
(2,6)\end{array}$ \\
\hline DeSmet et al. (2018) & $\begin{array}{l}\text { Design an intervention to } \\
\text { increase positive witness } \\
\text { behavior and reduce } \\
\text { negative witness behavior in } \\
\text { adolescent CB }\end{array}$ & $\begin{array}{l}216 \text { 8th graders ( } 60 \% \\
\text { female; } 13-14 \text { years); } 2 \\
\text { schools; Belgium. }\end{array}$ & $\begin{array}{l}\text { Demographic information; } \\
\text { involvement in bullying and } \\
\text { CB; witness behavior and its } \\
\text { determinants (DeSmet et al., } \\
\text { 2016a; b); KIDSCREEN scale } \\
\text { (Ravens et al., 2010). }\end{array}$ & $\begin{array}{l}\text { The intervention improved } \\
\text { prosocial skills, self- } \\
\text { efficacy and the intention } \\
\text { to act as a positive witness. } \\
\text { It increased CBW, CB } \\
\text { awareness and life quality. } \\
(1,2)\end{array}$ \\
\hline Díaz and Fite (2019) & $\begin{array}{l}\text { Examine links between CV, } \\
\text { substance use, and anxiety } \\
\text { and depression symptoms, } \\
\text { considering physical/ } \\
\text { relational victimization over } \\
1 \text { academic year. }\end{array}$ & $\begin{array}{l}2606 \text { th-8th graders } \\
\left(47 \% \text { female; } M_{\text {age }}=\right. \\
12.24) ; \text { USA. }\end{array}$ & $\begin{array}{l}\text { Demographic info and } \\
\text { substance use survey; } \\
\text { European CB Intervention } \\
\text { Project Quest. (del Rey et al., } \\
\text { 2015); Short Mood and } \\
\text { Feelings Quest. (Angold \& } \\
\text { Costello, 1987); Emotional } \\
\text { Distress \& Anxiety Scale (Ader } \\
\text { 2007); Social Experience } \\
\text { Quest. (Cullerton \& Crick, } \\
\text { 2005). }\end{array}$ & $\begin{array}{l}\mathrm{CV} \text { was related to higher } \\
\text { risk for substance use, but } \\
\text { not to anxiety or } \\
\text { depression, considering } \\
\text { physical and relational } \\
\text { victimization. (3) }\end{array}$ \\
\hline Doumas and Midgett (2020) & $\begin{array}{l}\text { Study the associations } \\
\text { among depressive and } \\
\text { anxiety symptoms with } \\
\text { CBW. }\end{array}$ & $\begin{array}{l}122 \text { 3rd-5th graders } \\
(43.8 \% \text { female; Mage = } \\
\text { 9.65); } 1 \text { school; USA. }\end{array}$ & $\begin{array}{l}\text { CBW questions; Olweus } \\
\text { Bullying Quest. (Olweus, } \\
\text { 1996); Epidemiological } \\
\text { Studies Depression (Weissman } \\
\text { et al., 1980); Social Anxiety } \\
\text { Scale (Greca \& Stone, 1993). }\end{array}$ & $\begin{array}{l}\text { CB witnessing was related } \\
\text { to depressive symptoms } \\
\text { and social anxiety with } \\
\text { higher levels than students } \\
\text { who witnessed bullying. } \\
(2,3,4)\end{array}$ \\
\hline Escortell, Aparisi, et al. (2020) & $\begin{array}{l}\text { Assess aggression and } \\
\text { personality traits in different } \\
\text { CB roles and the influence of } \\
\text { these levels predicting } \\
\text { participation in other roles. }\end{array}$ & $\begin{array}{l}548 \text { 5th-6th graders } \\
\text { (49.8 female; Mage }= \\
\text { 10.95); Spain. }\end{array}$ & $\begin{array}{l}\text { CB: Peer Harassment } \\
\text { Screening (Garaigordobil, } \\
\text { 2013); Big Five Quest. For } \\
\text { children (Barbaranelli et al., } \\
\text { 2003); Aggression Quest. } \\
\text { (Buss \& Perry, 1992). }\end{array}$ & $\begin{array}{l}\text { Verbal aggression and } \\
\text { extraversion were factors to } \\
\text { be victims; anger explained } \\
\text { being a victimized bully; } \\
\text { and agreeableness a } \\
\text { predictor to be CB victim } \\
(2,3) \text {. }\end{array}$ \\
\hline $\begin{array}{l}\text { Escortell, Delgado, and } \\
\text { Martínez-Monteagudo (2020) }\end{array}$ & $\begin{array}{l}\text { Define an explanatory model } \\
\text { on CV through a structural } \\
\text { equations analysis, on the } \\
\text { basis of CV relations with } \\
\text { aggressiveness, school } \\
\text { anxiety and self-concept. }\end{array}$ & $\begin{array}{l}542 \text { 5th-6th graders } \\
\text { (49.8 female; Mage }= \\
\text { 10.97); Spain. }\end{array}$ & $\begin{array}{l}\text { Self-Description Quest. } \\
\text { (Marsh, 1992); CB: Peer } \\
\text { Harassment Screening ( } \\
\text { Garaigordobil, 2013); } \\
\text { Aggression Quest. (Buss \& } \\
\text { Perry, 1992); School Anxiety } \\
\text { Inventory for Primary } \\
\text { Education (García-Fernández } \\
\text { et al., 2014). }\end{array}$ & $\begin{array}{l}\text { Self-concept and anxiety } \\
\text { were negatively related to } \\
\mathrm{CV} \text {, but positively related to } \\
\text { aggressiveness. The } \\
\text { psychological regulation } \\
\text { could prevent the risk of } \\
\text { being a CV. (3) }\end{array}$ \\
\hline Authors (year) & Purpose/s & Sample & Design/instruments & $\begin{array}{l}\text { Findings/conclusions } \\
\text { (theme/s) }\end{array}$ \\
\hline Fahy et al. (2016) & $\begin{array}{l}\text { Evaluate longitudinal } \\
\text { associations between CB } \\
\text { involvement and adolescent } \\
\text { mental health. }\end{array}$ & $\begin{array}{l}24807 \text { th graders ( } 44.8 \\
\text { female; } 12-13 \text { years); } 25 \\
\text { schools; England. }\end{array}$ & $\begin{array}{l}\text { Measure of depressive } \\
\text { symptoms, social anxiety } \\
\text { symptoms and mental well- } \\
\text { being. CB involvement (Ybarra } \\
\text { et al., 2007). }\end{array}$ & $\begin{array}{l}\mathrm{CB} \text { and potential of } \mathrm{CV} \\
\text { were risk factors for } \\
\text { depressive/anxiety } \\
\text { symptoms and below } \\
\text { average well-being. (3) }\end{array}$ \\
\hline $\begin{array}{l}\text { Garaigordobil and } \\
\text { Martínez-Valderrey (2016) }\end{array}$ & $\begin{array}{l}\text { Assess the effects of a } \\
\text { program (Cyberprogram 2.0) }\end{array}$ & & $\begin{array}{l}\text { Adolescents' Premeditated } \\
\text { and Impulsive Aggressiveness }\end{array}$ & $\begin{array}{l}\text { Cyberprogram } 2.0 \text { could } \\
\text { have a positive impact on } \\
\text { (continued on next page) }\end{array}$ \\
\hline
\end{tabular}


Table 2 (continued)

\begin{tabular}{|c|c|c|c|c|}
\hline Authors (year) & Purpose/s & Sample & Design/instruments & $\begin{array}{l}\text { Findings/conclusions } \\
\text { (theme/s) }\end{array}$ \\
\hline Gradinger et al. (2016) & $\begin{array}{l}\text { to prevent and reduce CB on } \\
\text { school aggressiveness and } \\
\text { violence. } \\
\text { Investigate the effectiveness } \\
\text { (T1) and sustainability (T2) } \\
\text { of the ViSC program (applied } \\
\text { for } 1 \text { year in Austria) to } \\
\text { prevent CV and CB within a } \\
\text { randomized control study. }\end{array}$ & $\begin{array}{l}176 \text { 8th graders }(56.3 \% \\
\text { female; } 13-15 \text { years); } 3 \\
\text { schools; Spain. } \\
\text { T1:2042 5th-7th graders } \\
\text { (47.6\% female; } \mathrm{M}_{\mathrm{age}}= \\
\text { 11.7); } 18 \text { schools. T2: } \\
\text { 659 6th-7th graders } \\
\text { (47.9\% female; } \mathrm{M}_{\mathrm{age}}= \\
12.7) ; 6 \text { schools. }\end{array}$ & $\begin{array}{l}\text { Quest. (Andreu, 2010); School } \\
\text { Violence Revised Quest. } \\
\text { (Álvarez-García et al., 2011). } \\
\text { Self-reported quest. }\end{array}$ & $\begin{array}{l}\text { different types of school } \\
\text { violence and different kinds } \\
\text { of aggressive behaviors. (1) } \\
\text { The ViSC program was } \\
\text { effective in preventing CB } \\
\text { and CV, and the effects } \\
\text { were sustainable after } 6 \\
\text { months. (1) }\end{array}$ \\
\hline Govender and Young (2018) & $\begin{array}{l}\text { Study the differences in } \\
\text { gender, age, grade, and } \\
\text { experiences of authoritarian } \\
\text { parenting among traditional } \\
\text { and CB perpetrators. }\end{array}$ & $\begin{array}{l}2726 \text { th-7th graders } \\
\left(63.6 \% \text { female; } M_{\text {age }}=\right. \\
\text { 12.08); } 4 \text { schools; South } \\
\text { Africa. }\end{array}$ & $\begin{array}{l}\text { Adapted version of the Revised } \\
\text { Olweus Bully/Victim Quest } \\
\text { (Olweus, 2007) and Parenting } \\
\text { Practices Quest (Robinson } \\
\text { et al., 1995) }\end{array}$ & $\begin{array}{l}\text { Bullying and CB were } \\
\text { related to authoritarian } \\
\text { parenting. Gender/age } \\
\text { were not significantly } \\
\text { linked to bullying. Grade } \\
\text { was significantly linked to } \\
\text { traditional/CB } \\
\text { perpetration. }(4,5,6)\end{array}$ \\
\hline Holfeld and Leadbeater (2017) & $\begin{array}{l}\text { Assess the concurrent and } \\
\text { longitudinal associations ( } 1 \\
\text { course) among early } \\
\text { adolescents' experiences of } \\
\text { school climate and CV in } \\
\text { relation to traditional } \\
\text { victimization using WITS } \\
\text { program. }\end{array}$ & $\begin{array}{l}7145 \text { th-6th graders } \\
\left(52 \% \text { female; } M_{a g e}=\right. \\
11.0) \text { at the beginning; } \\
638\left(52 \% \text { female; } M_{a g e}\right. \\
=11.48) \text { at the end; } 27 \\
\text { schools; Canada. }\end{array}$ & $\begin{array}{l}\text { Social Experience Quest } \\
\text { (Desjardins et al., 2013); } \\
\text { Development Program School } \\
\text { Climate Surveys: Elementary- } \\
\text { Middle School (Haynes et al., } \\
\text { 1997); CB Behavior and } \\
\text { Victimization Experiences for } \\
\text { School Child Scale (Holfeld \& } \\
\text { Leadbeater, 2015). }\end{array}$ & $\begin{array}{l}\text { Students who experienced } \\
\text { a better school climate } \\
\text { reported less CV within and } \\
\text { across time. A safe and } \\
\text { supportive school } \\
\text { environment could prevent } \\
\text { CV inside and outside the } \\
\text { school. }(1,3)\end{array}$ \\
\hline Knauf et al. (2018) & $\begin{array}{l}\text { Detect differences in the } \\
\text { social-cognitive and affective } \\
\text { reactions of witnesses to } \\
\text { school bullying/CB. }\end{array}$ & $\begin{array}{l}486 \text { 6th-8th graders } \\
\text { (56\% female; } \mathrm{M}_{\mathrm{age}}= \\
\text { 12.95); } 10 \text { schools; } \\
\text { Germany. }\end{array}$ & $\begin{array}{l}\text { Self-reported quest. to assess } \\
\text { students' witness experiences } \\
\text { and Social-Cognitive and } \\
\text { Affective Reactions to } \\
\text { Bullying. }\end{array}$ & $\begin{array}{l}\text { During CB, moral } \\
\text { disengagement was } \\
\text { stronger, while feelings of } \\
\text { responsibility and defender } \\
\text { self-efficacy were weaker. } \\
(2,4)\end{array}$ \\
\hline Longobardi et al. (2020) & $\begin{array}{l}\text { Investigate the relation } \\
\text { between time perspectives } \\
\text { and } \mathrm{CB} / \mathrm{CV} \text {. }\end{array}$ & $\begin{array}{l}4036 \text { th-8th graders } \\
\left(56 \% \text { female; } \mathrm{M}_{\mathrm{age}}=\right. \\
12.2) ; \text { Italy. }\end{array}$ & $\begin{array}{l}\text { Florence CB/CV Scales } \\
\text { (Palladino et al., 2015); Time } \\
\text { Perspective Inventory } \\
\text { (Zimbardo \& Boyd, 2015); } \\
\text { Student Perception of } \\
\text { Affective Relationship with } \\
\text { Teacher (Koomen \& Jellesma, } \\
\text { 2015); Strength and } \\
\text { Difficulties Quest. (Italian } \\
\text { teacher version; Marzocchi } \\
\text { et al., 2004). }\end{array}$ & $\begin{array}{l}\text { Time perspective and CV/ } \\
\text { CB showed correlations. } \\
\text { Cybervictims reported } \\
\text { negative relations with past } \\
\text { orientations, but the } \\
\text { involvement in active CB } \\
\text { was negatively related to } \\
\text { past and future } \\
\text { orientations. Future } \\
\text { orientations could be a } \\
\text { protective factor against } \\
\text { involvement in CB. (3) }\end{array}$ \\
\hline López-Pradas et al. (2017) & $\begin{array}{l}\text { Design a cybergossip quest } \\
\text { and adapt a CB quest to } \\
\text { primary school students and } \\
\text { analyze the influence of } \\
\text { cybergossip on CB and CV. }\end{array}$ & $\begin{array}{l}\text { 866 4th-6th graders } \\
\left(52.9 \% \text { female; } \mathrm{M}_{\mathrm{age}}=\right. \\
11.21) \text {; Spain. }\end{array}$ & $\begin{array}{l}\text { Cybergossip-Q-Primary; } \\
\text { Adaptation of the European CB } \\
\text { Intervention Project Quest. } \\
\text { (del Rey et al., 2015). }\end{array}$ & $\begin{array}{l}\text { Significant relationship } \\
\text { between cybergossip and } \\
\text { CB was found. (3) }\end{array}$ \\
\hline Authors (year) & Purpose/s & Sample & Design/instruments & $\begin{array}{l}\text { Findings/conclusions } \\
\text { (theme/s) }\end{array}$ \\
\hline $\begin{array}{l}\text { Machimbarrena and } \\
\text { Garaigordobil (2017) }\end{array}$ & $\begin{array}{l}\text { Examine the bullying/CB } \\
\text { prevalence and explore the } \\
\text { quantity of bullying/CB } \\
\text { behavior suffered, } \\
\text { perpetrated, and observed in } \\
\text { public/private schools. }\end{array}$ & $\begin{array}{l}1993 \text { 5th-6th graders } \\
\left(48.8 \% \text { female; } M_{\text {age }}=\right. \\
\text { 10.68); } 25 \text { schools; } \\
\text { Spain. }\end{array}$ & $\begin{array}{l}\text { CB: Screening of Peer } \\
\text { Harassment (Garaigordobil, } \\
\text { 2013). }\end{array}$ & $\begin{array}{l}\text { No differences in bullying/ } \\
\text { CB between schools for } \\
\text { pure-victims, witnesses, } \\
\text { pure-bullies, and bully- } \\
\text { victims. More bullying/CB } \\
\text { were perpetrated, suffered, } \\
\text { and observed in public } \\
\text { schools. }(2,4,6)\end{array}$ \\
\hline $\begin{array}{l}\text { Machimbarrena and } \\
\text { Garaigordobil (2018) }\end{array}$ & $\begin{array}{l}\text { Analyze bullying and CB } \\
\text { prevalence according to } \\
\text { students' gender and to } \\
\text { explore averages in } \\
\text { behaviors suffered, } \\
\text { perpetrated, and observed. }\end{array}$ & $\begin{array}{l}1993 \text { 5th-6th graders } \\
\left(48.8 \% \text { female; } M_{\text {age }}=\right. \\
\text { 10.68); } 25 \text { schools; } \\
\text { Spain. }\end{array}$ & $\begin{array}{l}\text { CB: Screening of Peer } \\
\text { Harassment (Garaigordobil, } \\
\text { 2013). }\end{array}$ & $\begin{array}{l}\text { Students showed similar } \\
\text { levels on witnesses, pure- } \\
\text { victims, and pure-bullies in } \\
\text { boys/girls. Girls observed } \\
\text { more sexual harassment } \\
\text { behaviors. Boys showed } \\
\text { higher CV levels, behaviors } \\
\text { perpetrated, bullied and }\end{array}$ \\
\hline
\end{tabular}

(continued on next page) 
Table 2 (continued)

\begin{tabular}{|c|c|}
\hline Authors (year) & Purpose/s \\
\hline Meter and Bauman (2018) & $\begin{array}{l}\text { Study the indirect link } \\
\text { between moral } \\
\text { disengagement about CB and } \\
\text { parental monitoring on } \\
\text { bullying and victimization } \\
\text { via CB involvement. }\end{array}$ \\
\hline Moyano et al. (2019) & $\begin{array}{l}\text { Assess the mediating role of } \\
\text { social integration and } \\
\text { relationships about the } \\
\text { factors associated with } \\
\text { bullying forms (relational, } \\
\text { aggressive, CB) suffered by } \\
\text { victims. }\end{array}$ \\
\hline
\end{tabular}

Sample Design/instruments

800 3rd-8th graders (52\% female); USA.

3407 th-6th graders $\left(52.4 \%\right.$ female; $\mathrm{M}_{\text {age }}=$ 11.42); 42 schools; Spain.
Navarro et al. (2018)

Authors (year)

Quintana-Orts and Rey (2018)

Sidera et al. (2020)

Solomontos-Kountouri et al. (2016)
Study the prevalence of CB among elementary school students, identify technological responses employed by cybervictims and examine the differences in the levels of coping resources and styles used between cybervictims and non-cybervictims.
Verify the differences

between groups of cybervictims regarding cyber-relationship motives and coping strategies for handling problems.

\section{Purpose/s}

Study how forgiveness is related to improved mental health after bullying transgressions.
1075 th-6th graders (50,5\% female; $10-12$ years); 5 schools; Australia.

1058 5th-6th graders (48,77\% female; $\mathrm{M}_{\mathrm{age}}=$ 11.08); 17 schools; Spain.

\section{Sample}

1044 early adolescents (50.47\% females; $M_{\text {age }}$ =13.09); 6 schools; Spain.

4646 3rd-6th graders (49\% female; $M_{\mathrm{age}}=$ 10.16); Spain. bullying and its links with the perceptions of students of being victims.
Children's Coping Scale (Cunningham, 2002); Adapted version of the CB Scale (Menesini et al., 2011); The People in My Life (Cook et al., 1995); Locus of Control Scale for Children (Nowicki \& Strickland, 1973); ModifiedRosenberg Self-Esteem Scale (Gray-Little et al., 1997); Checklist of Specific Technological Responses.

Spanish CB Quest (Estévez et al., 2010); Coping Strategies (Morales-Rodríguez et al., 2012); The Bullying Involvement Scale (Fitzpatrick \& Bussey, 2011); Cyberrelationship motives (Wang \& Chang, 2010).

\section{Design/instruments}

European Bullying Intervention Project Quest. (Ortega-Ruiz et al., 2016); Values in Action Inventory for Youth (Park et al., 2006); Satisfaction with Life Scale (Diener et al., 1985); Suicidal Behavior Quest. (Osman et al., 2001).

European Bullying

Intervention Project Quest. (Ortega-Ruiz et al., 2016); reduced version-European $\mathrm{CB}$ Intervention Project Quest. (Ortega-Ruiz et al., 2016); Perception of being a victim/ cybervictim.

Self-reported scales of one item (CB and CV; Smith et al., 2008); items of bullying/
Findings/conclusions (theme/s)

observed, and victimaggressive. $(2,4,6)$ Moral disengagement about CB and parental monitoring affected $\mathrm{CB}$ involvement. CB involvement predicted traditional victimization and bullying. $(3,4,5)$ Social integration and low perception of negative relationships mediated to predict bullying forms, being the first strongly correlated with bullying. School type was related to negative relations/good friends, and both predicted social integration. $(4,6)$ $13.1 \%$ of participants reported single episodes of CV. Technological responses employed by cybervictims included blocking, deleting, and changing passwords. Those who reported one episode of CB had higher levels of self-esteem compared to never or repeated CB. No significant differences were found in coping styles, locus of control and attachment. $(2,5)$ Cybervictims used the Internet to create new relationships, search for anonymity, escape the real world and compensate their lack of social skills. Severe cybervictims used less effective social problem-solving strategies than non-/occasional victims. $(2,3)$ Findings/conclusions (theme/s) Students with a higher level of forgiveness were less likely to report mental health problems after a bullying experience (in both traditional and online form) compared to teenagers with low levels of forgiveness. (4)

Victimization and students' perceptions of it were reduced with the school grade, but CV was stable in boys and increased in girls. Boys were more victimized than girls. CV could be related with victimization. $(4,6)$

The program was more effective for 7 th than 8 th graders. $(1,6)$

(continued on next page) in Cyprus and to investigate $\quad\left(48.9 \%\right.$ female; $\mathrm{M}_{\text {age }}=$ its effectiveness within a
(48.9\% female; $M_{\text {age }}=$
12.6); 6 schools; Cyprus. 
Table 2 (continued)

\begin{tabular}{|c|c|}
\hline Authors (year) & Purpose/s \\
\hline & $\begin{array}{l}\text { quasi-experimental } \\
\text { longitudinal study. }\end{array}$ \\
\hline Vivolo-Kantor et al. (2020) & $\begin{array}{l}\text { Evaluate the effects of the } \\
\text { Dating Matters prevention } \\
\text { model on CB, bullying and } \\
\text { physical violence. }\end{array}$ \\
\hline Wang et al. (2018) & $\begin{array}{l}\text { Assess the links among } \\
\text { school, individual and } \\
\text { familiar predictors of } \\
\text { suicidal thoughts and } \\
\text { behaviors, using data from } \\
\text { the Georgia Student Health } \\
\text { Survey 2.0. }\end{array}$ \\
\hline Wegge et al. (2016) & $\begin{array}{l}\text { Analyze the interrelationship } \\
\text { between adolescents' social } \\
\text { status (popularity) and CB } \\
\text { behavior. }\end{array}$ \\
\hline Wright (2016) & $\begin{array}{l}\text { Investigate the longitudinal } \\
\text { buffering role of different } \\
\text { parental mediation strategies } \\
\text { between CB victims and } \\
\text { psychosocial adjustment } \\
\text { difficulties. }\end{array}$ \\
\hline
\end{tabular}

12,511 6th-8th Asian American graders (50.05\% female); 510 schools; USA.

154 7th graders $(58.2 \%$ female; 12-14 years); Belgium.

568 8th graders $(53 \%$ female; 13-15 years); 1 school; USA.

\section{Purpose/s}

Examine with two studies the early students' attributions and emotional distress based on social context in (1) ambiguous social situations and (2) hypothetical unambiguous victimization scenarios. Thus, it was also examined one year later.

\section{Wright (2017b)}

Wright (2017c)
Assess the mitigating effect of social support from parents, teachers and friends obtained one year later the connection between $\mathrm{CV}$ and depression.

Check the links between parental mediation strategies and $\mathrm{CB}$ behavior/CV, and cyber-trolling behavior/CV, as well as examine the gender role in these mediations.
Sociometric and perceived popularity (self-constructed) and Involvement in traditional bullying and CB (selfconstructed).

CV scale (Wright \& Li, 2013); Anxiety Scale for Children (March et al., 1997); Mediation of Technology Usage (Arrizabalaga et al., 2010); UCLA Loneliness Scale (Russell, 1996); Face-to-face victimization Quest. (Wright et al., 2014); Depression Scale (Radloff, 1977).

\section{Sample}

(1) 4397 th-8th graders $\left(50.57 \%\right.$ female; $\mathrm{M}_{\mathrm{age}}=$ 12.76). (2) 414 7th-8th graders (212 females; $\left.\mathrm{M}_{\mathrm{age}}=12.68\right)$; 1 school; USA.

131 8th graders $(27 \%$ female; $13-15$ years; cognitive disabilities and/or developmental disorders); USA.

68 8th graders ( $52 \%$ female; $\left.\mathrm{M}_{\mathrm{age}}=13.48\right) ; 1$ school; USA.

\section{Design/instruments}

(1) Face-to-face and cyber ambiguous peer conflicts (Crick \& Dodge, 1996); Faceto-face and cyber emotions; Face-to-face and cyber attributions. (2) Emotional distress for face-to-face and cyber vignettes; Face-to-face attributions and cyber vignettes (Wright \& Li, 2012). (1-2) Face-to-face relational aggression (Wright et al., 2012); Self-reported CB ( Wright \& Li, 2013).

CV scale (Wright \& Li, 2013); Perceived Social Support from Parents, Teachers, and Friends (Malecki et al., 2000); and Depression Scale (Radloff, 1977).

Mediation of Technology Usage (Arrizabalaga et al., 2010); and CV scale (Wright \& Li, 2013).
Findings/conclusions (theme/s) $\begin{array}{ll}3301 \text { 6th-8th graders } & \text { Items from: Illinois Bully Sca } \\ \text { (53\% female; } \mathrm{M}_{\mathrm{age}}= & \text { (Espelage \& Holt, 2001); }\end{array}$

Foundation, 2001); to measure Georgia School Climate Survey

.
and behaviors (more in girls), but school climate (only in boys), parental involvement (only in girls) and gender buffered these relationships. $(3,4,5,6)$ Bullying was not associated with popularity. $\mathrm{CB}$ predicted perceived popularity over time, but not socially measured popularity. (6)

CV was linked to parental mediation, depression, anxiety and loneliness while such associations were negative for coviewing mediation and instructive mediation. High levels of these types of mediation made the relationship of CV to depression more negative. $(3,5)$

\section{Findings/conclusions} (theme/s) Feelings of sadness, anger, hostile, self-blame, and aggressor-blame attributions were more often elicited from face-toface victimization than cyber victimization. Anger mediated the relationship between attributions and face-to-face and cyber aggression. $(3,4)$

High levels of perceived parents and teachers' social support weakened the relationship between CV and depression. $(3,5)$

Parents' guidance could help reduce the perpetration of $\mathrm{CB}$. The connection between girls restrictive mediation/CV was more positive than to boys, but it was more negative between guided mediation/CV. $(5,6)$ 
Table 2 (continued)

\begin{tabular}{|c|c|c|c|c|}
\hline Authors (year) & Purpose/s & Sample & Design/instruments & $\begin{array}{l}\text { Findings/conclusions } \\
\text { (theme/s) }\end{array}$ \\
\hline Wright and Wachs (2019) & $\begin{array}{l}\text { Evaluate the effect of } \\
\text { ethnicity in the associations } \\
\text { among CV, school- } \\
\text { belongingness, and } \\
\text { psychological consequences. }\end{array}$ & $\begin{array}{l}4167 \text { th-8th graders } \\
\text { (46\% female; Latin and } \\
\text { white; } M_{\text {age }}=13.89 \text { ); } 1 \\
\text { school; USA. }\end{array}$ & $\begin{array}{l}\text { Depression Scale (Radloff, } \\
\text { 1977); Anxiety Scale for } \\
\text { Children (March et al., 1997); } \\
\text { School-belongingness } \\
\text { (Goodenew, 1993); UCLA } \\
\text { Loneliness Scale (Russell, } \\
\text { 1996); Face-to-face } \\
\text { victimization Quest. (Wright } \\
\text { et al., 2014); CV scale (Wright } \\
\text { \& Li, 2013). }\end{array}$ & $\begin{array}{l}\text { Positive relation into CV } \\
\text { with loneliness and } \\
\text { depression and anxiety was } \\
\text { reinforced by low levels of } \\
\text { belongingness. This CV } \\
\text { threatens belongingness of } \\
\text { the students and their } \\
\text { emotional adjustment. } \\
(3,6)\end{array}$ \\
\hline Wright and Wachs (2020) & $\begin{array}{l}\text { Examine the influence of } \\
\text { gender and stereotype traits } \\
\text { (femininity and masculinity) } \\
\text { in CV behaviors using } \\
\text { technologies. }\end{array}$ & $\begin{array}{l}456 \text { 8th graders }(49.56 \% \\
\left.\text { female; } M_{\text {age }}=13.66\right) ; 2 \\
\text { schools; USA. }\end{array}$ & $\begin{array}{l}\text { Bem Sex Role Inventory (Bem, } \\
\text { 1974); and CV scale (Wright \& } \\
\text { Li, 2013). }\end{array}$ & $\begin{array}{l}\text { Students with high } \\
\text { feminine traits or low levels } \\
\text { of both traits had higher } \\
\text { levels of CV than students } \\
\text { with high masculine traits/ } \\
\text { both traits. Boys reported } \\
\text { main effects of CV types } \\
\text { and girls an interaction } \\
\text { between CV-techs. (6) }\end{array}$ \\
\hline Zhang et al. (2020) & $\begin{array}{l}\text { Investigate the trajectories of } \\
\mathrm{CB} \text { and neuroticism, as well } \\
\text { as their associations. }\end{array}$ & $\begin{array}{l}4327 \text { 3rd-4th graders; } \\
\text { (44.6\% female; } M_{\mathrm{age}}= \\
\text { 9.94); } 13 \text { schools; China. }\end{array}$ & $\begin{array}{l}\text { Abbreviated Junior Eysenck } \\
\text { Personality Quest. (Francis, } \\
\text { 1996); adaptation of the } \\
\text { Electronic Bullying Quest. } \\
\text { (EBQ; Moore et al., 2012). }\end{array}$ & $\begin{array}{l}\mathrm{CB}, \mathrm{CV} \text {, and neuroticism } \\
\text { were correlated at baseline } \\
\text { and decreased over time } \\
\text { parallelly. Gender was } \\
\text { associated to the decreasing } \\
\text { of three variables, but age } \\
\text { only with } \mathrm{CB} .(3,6)\end{array}$ \\
\hline
\end{tabular}

Themes: (1) Studies investigating the effectiveness of CB programs; (2) Studies investigating the responses of the students' roles related to CB; (3) Studies investigating the relationship between $\mathrm{CB} / \mathrm{CV}$ and psycho-social variables; (4) Studies comparing the relationship between bullying and CB; (5) Studies investigating the effects of external factors on the students' responses; (6) Studies comparing students' socio-demographic variables. Instruments references are available in its respective study.

\section{Method}

This systematic review was registered in PROSPERO (CRD42020214226), and it was conducted using PRISMA guidelines (Moher, Liberati, Tetzlaff, Altman, \& ThePRISMA Group, 2009) to promote quality and reliability. The review followed an empirical approach, which delineate specific parameters to select primary data, to provide a consolidated picture (Oakley, 2012). This process ensures data synthesis using impartial lens (Hemingway \& Brereton, 2009).

\subsection{Data sources and search strategy}

In order to provide an extensive review of the literature, both electronic and manual searches were conducted. On the one hand, the electronic search complied a review across several databases from the beginning of 2016 to the end of 2020: Education Information Resource Center (ERIC), Web of Science, Scopus, Scielo, PsycArticles and PsycINFO. The keywords string incorporated the following terms: "cyberbullying”, "cyber bullying”, "cyber bullying”, "primary school”, "middle school”, “elementary school”, and "high school”. The Boolean operators "OR", "AND" and "NOT" (not for "high school") were used. On the other hand, the manual search involved a review of previous $C B$ reviews and the main journals that have published on the topic. All searches were exported to Mendeley ${ }^{\circledR}$ software by two of the authors and reviewed by the other authors to guarantee the reliability of the search process. On the other hand, the manual search was made screening relevant journals publishing about $\mathrm{CB}$, as well as other reviews and meta-analysis on this topic. In this search, articles not found in the electronic search were also included.

\subsection{Inclusion and exclusion criteria}

The articles' eligibility involved inclusion criteria to guarantee consistency in the purposes of the review (see PRISMA flow diagram in Fig. 1). Only original articles published in English and in peer-review journals from 2016 to 2020, with samples that included elementary and/or middle school students, which focused on CB were selected. The sample focused on children aged six to nine years and early adolescents aged 10-14 years in educational contexts. This last age group (early adolescence) are at higher risk of being involved in CB (e.g., Cole et al., 2016; Holfeld \& Leadbeater, 2015).

First, 83 duplicated documents of different databases were removed. In the first level of exclusion, titles and abstracts were scrutinized, and 822 documents were removed based on the following criteria: (a) not original articles (e.g., reviews, meta-analysis, book chapters or questionnaires validations; 120); (b) did not assess CB (e.g., only bullying, crimes, laws, parental control or different Internet uses not-related with CB; 120); (c) including high school students or adults (340) or not including students (e.g., parents, 
teachers or nurses; 36); (d) not published in journals indexed in JCR (107); (e) published in 2015 or 2021 (3).

Second, 96 full-text articles were screened. 64 were removed in a second level of exclusion because: (a) lack of relevant information (e.g., students' grade); (b) high school students, teachers or parents included; (c) CB was not included among the variables assessed; or (d) longitudinal studies which started data collection with middle school graders, but finished with high school graders. Finally, 32 studies were included from the electronic search and 9 from the manual search.

\subsection{Quality assessment}

The whole review process was conducted by several authors and it was evaluated with the PRISMA (2009) checklist. Moreover, the Mixed Methods Appraisal Tool (MMAT; Hong, Fàbregues, Bartlett, Boardman, Cargo, Dagenais et al., 2018) was used to assess the selected articles' quality. The MMAT includes a list of defined items to evaluate the articles included in systematic reviews according to the article type. The scores were set as low (1-2), medium (3) and high (4-5) for quantitative studies (there were no studies with qualitative/mixed designs), based on the tool's matrix (Hong et al., 2018). Each item was scored as Yes (1), Cannot tell (0.5) and No (0). Table 1 shows a summary of this assessment.

\subsection{Thematic analysis}

To facilitate the analysis of the studies' findings, the authors of this review identified common themes using an inductive lens and following the process defined by Braun and Clarke (2006). It involves data familiarization and coding (during the screening, full-text reading and quality review process), theme searching and review (authors consolidated data to identify themes) and defining and naming themes (with the agreement of all authors after the review of ideas through individual/collaborative writing and reviewing; Creswell \& Miller, 2000). From this process, the following themes were extracted to facilitate the analysis of the studies' objectives and results: (1) CB/CV and psycho-social variables; (2) Students' sociodemographic variables; (3) Connections between bullying and CB; (4) Students' roles related to CB; (5) External factors and students' responses; and (6) Effectiveness of CB programs. Some studies were linked to various themes (e.g., evaluating the effectiveness of a CB program and comparing gender/ages).

\section{Results and discussion}

This systematic literature review sought to assess the current state of literature concerning CB in elementary and/or middle school. After the review process, 43 articles were identified based on the eligibility criteria, as shown in Fig. 1. First, each article's most relevant information was analyzed and discussed using the following items (see in Table 2) to answer the first research question of this review: 'authors' (publication year); 'purpose/s'; 'sample'; 'design/instruments'; 'main findings/conclusions (theme/s of the thematic analysis)'. Then, this information was analyzed and discussed based on these items, and results/conclusions of the articles selected were analyzed and discussed according to the themes extracted to answer the second research question of the review.

\subsection{Purpose/s}

The studies' main purposes were related to 'the influence of CB/CV on psycho-social variables' (19 articles) and 'the comparison between students' socio-demographic variables' (17 articles). Among the first group, the largest number focused on CB/CV and anxiety (7 articles), depression (6 articles), neuroticism ( 2 articles) or empathy, in the same line of previous reviews including high school students (Kowalski et al., 2014). Among the second group, students' gender was the most popular (13 articles) (Sun, Fan, \& Du, 2016), followed by school grade (7 articles). Only four studies assessed other variables like type of school (2 articles), social status (popularity; Wegge, Vandebosch, Eggermont, \& Pabian, 2016) or ethnic background (Wright \& Wachs, 2019).

The purposes 'compare the relationship between bullying and CB' (13 articles) and 'investigate the responses of the students' roles related to CB' (13 articles) were also extensively researched. First, the study of the connections between bullying and CB seem to be justified by their links and transference (Görzig \& Machackova, 2015). Several studies aimed to compare the transference of bullying behaviors between online and offline contexts (11 articles), and only one studied different bullying forms (relational, aggressive and CB; Moyano, Ayllón, Antoñanzas, \& Cano, 2019). Second, several studies explored how students were immersed in different CB situations from different roles (Schultze-Krumbholz, Hess, Pfetsch, \& Scheithauer, 2018). Most of them evaluated the bully, victim and witness roles ( 5 articles), but others only investigated victims ( 4 articles), witness ( 3 articles) or bully and victims (Chu, Fan, Liu, \& Zhou, 2018b; Escortell, Aparisi, Martínez-Monteagudo, \& Delgado, 2020).

Finally, some studies investigated potential solutions to CB: 'the effects of external factors on the students' responses' (9 articles) and 'the effectiveness of CB programs' (10 articles). Some external factors were researched to assess their influence on the way students faced CB situations. Some of these factors were parental mediation/influence (7 articles), school, individual and familiar predictors (2 articles), mediating role of social integration (Moyano et al., 2019) or social context (Wright, 2017a). Conversely, a great variety of programs were conducted on early adolescents such as ViSC (2), WITS (Holfeld \& Leadbeater, 2017), Cyberprogram 2.0 (Garaigordobil \& Martínez-Valderrey, 2016), 'Datting matters' program (Vivolo-Kantor et al., 2020) or using WhatsApp as tool (2 articles). Previous reviews including high school graders reported the use of other programs, suggesting that intervention and prevention programs can be effective (Couvillon \& Ilieva, 2011; Gaffney, Farrington, Espelage, \& Ttofi, 2019). 


\subsection{Sample}

Regarding the geographical context where the studies were conducted, USA (12 articles) and Spain (12 articles) where the top countries, followed by Belgium, China, Israel and South Africa ( 2 articles each). The rest of the studies were conducted in 10 different countries (1 article each) such as Canada (Holfeld \& Leadbeater, 2017) or Germany (Knauf, Eschenbeck, \& Hock, 2018).

In relation to the percentage of girls who participated, most studies included $40-60 \%$ girls (38 articles), except three where the sample included 39\% (Chu et al., 2018b), 27\% (Wright, 2017b), and 63.6\% girls (Govender \& Young, 2018). The studies included in this review provided conclusions considering the influence on boys and girls differently or comparing their results between similar samples of both genders.

Concerning the participants' educational stage, 22 studies were conducted only at middle-school level (Delgado \& Escortell, 2018; Knauf et al., 2018), 18 were conducted in elementary and middle school (López-Pradas, Romera, Casas, \& Ortega-Ruiz, 2017; Meter \& Bauman, 2018) and only three studies in 2020 investigated elementary school students. To our knowledge, there are no previous reviews on the impact of $\mathrm{CB}$ on elementary and/or middle school students exclusively, even though the impact of social media and new techs in these grades is high (Myers \& Cowie, 2019; Tokunaga, 2010). This review included several articles (43 articles) published in the last five years, showing the growing interest at these school stages (elementary and middle school) in comparison with reviews that included them joined with high school (e.g., Kowalski et al., 2014; Tokunaga, 2010; Zych et al., 2016). Future lines of research should focus on these ages.

\subsection{Design/instruments}

Most studies used a quantitative research approach (23 articles) (e.g., Govender \& Young, 2018; Machimbarrena \& Garaigordobil, 2017) describing the assessed variables, but not drawing any causal relationship. Additionally, 15 quantitative non-randomized (e.g., Holfeld \& Leadbeater, 2017; Wright \& Wachs, 2019) and six quantitative randomized controlled trials (e.g., Fahy et al., 2016; Gradinger, Yanagida, Strohmeier, \& Spiel, 2016) were conducted. Six articles used a longitudinal research design (e.g., Cole et al., 2016; Díaz \& Fite, 2019).

Only one study used qualitative methods to assess students' perceptions on a CB prevention program (Cuesta, Hennig, Duque, \& Malfasi, 2020). For this reason, the lack of studies using qualitative methodologies at these ages should also be highlighted. Dennehy et al. (2020) performed a review of qualitative studies which concluded that the features of CB identified in young people's characterization can help to develop a deeper insight into CB. Furthermore, it allows to foreground young people's conceptions and subjective experiences of CB (Dennehy et al., 2020; Mishna, 2004). Only 13 studies were reported from 2008 to 2015. None of these studies were included in the present review because of the publication date and/or the students' grade. Future research should use this methodological approach in order to gain a deeper understanding on the students' opinions on this phenomenon.

A wide variety of assessment instruments were used in the different studies. The questionnaires used were the result of mixing different scales based on the research aims. In most cases, questionnaires were self-reported to adapt to specific contexts. Similar instruments were found only in those articles of the same authors or those that were part of the same study (e.g., Machimbarrena \& Garaigordobil, 2017; Machimbarrena \& Garaigordobil, 2018). Similar results were found in a previous systematic review conducted in adults (Jenaro et al., 2020), where the most frequent scales were used by the same group of researchers. CV scale (Wright \& Li; 2013) (6 articles) and Screening for Peer Bullying (Garaigordobil, 2013) (4 articles) were the most widely used scales. The only qualitative study included in this review used two-semi-structured focus groups and students' forum postings in a web-based platform (Cuesta et al., 2020).

\subsection{Findings/conclusions on $C B / C V$ and psychosocial variables}

Several articles reported the effects of CB or CV as risk factors in the increase of students' anxiety and depressive symptoms in elementary and middle school students (8 articles) (e.g., Cole et al., 2016; Wright, 2017b) which, in turn, could lead to increased levels of withdrawal/loneliness in middle school (Coelho \& Romao, 2016; Wright, 2016; Wright \& Wachs, 2019) or decrease their well-being (Fahy et al., 2016). Even those elementary students who witnessed CB showed high levels of depressive symptoms and social anxiety (Doumas \& Midgett, 2020). Consistent with the previous article, Escortell, Aparisi, et al. (2020) suggest that 10-13-year-old students who are less aggressive and have an adaptive personality structure are at risk of suffering from, engaging in and observing CB. Thus, the improved psycho-emotional adjustment of the youngest students may help to prevent the risk of being victimized over the Internet (Escortell, Delgado, \& Martínez-Monteagudo, 2020). In this sense, schools must try to conduct intervention programs to promote students' feelings of competence and empowerment (e.g., transferring autonomy and responsibility from teacher to students or adapting tasks to all students' abilities) to help their adjustment and be able to face CB situations.

Previous results agreed with other studies including higher graders (Calvete et al., 2016; Chu et al., 2018a; Wang et al., 2019). Parents/teachers were pointed as a solution to weaken the CV-depression links in middle school students (Wright, 2017b), since they can offer guidance or advice, acting as counselors and supporters. On the other hand, Díaz and Fite (2019) did not found CV as a risk factor in the increase of students' depression/anxiety in middle school students, but they found it between CV and risk of substance use. A previous meta-analysis reported, CB perpetration and CV have strong positive connections with drug and alcohol use in older students (Kowalski et al., 2014). Therefore, CB prevention at younger grade levels could be helpful to prevent the onset of drug and alcohol use, given evidence that $\mathrm{CB}$ involvement may increase the risk of use at higher grade levels. More research should evaluate the links between these variables in primary and middle school students. 
Conversely, those cybervictims who lived several CB scenarios significantly decreased their self-esteem and self-concept in elementary and middle school students (Escortell, Delgado, \& Martínez-Monteagudo, 2020; Muller, Skues, \& Wise, 2017), even in older students (Palermiti et al., 2017; Wachs et al., 2020). The effects of CB in students' well-being could lead to the increase of neuroticism in elementary school students (Zhang, Huebner, \& Tian, 2020) or suicidal thoughts in early adolescents (Wang, La Salle, Wu, Do, \& Sullivan, 2018). These results are in line with previous research including high school graders (DeSmet et al., 2019; Kowalski et al., 2014). Moreover, middle school students' active involvement in CB perpetration was negatively correlated with future orientation (Longobardi et al., 2020). In this sense, school-based prevention efforts may benefit from focusing on students' future orientations to protect against involvement in CB (Nocentini et al., 2010).

Finally, cybervictims in older ages used to use Internet to build new relationships and search anonymity (Peter \& Petermann, 2018) instead of loneliness. Middle school cybervictims seemed to have problems with the use of effective social problem-solving strategies, resulting in alienation from social relationships (Navarro, Larrañaga, \& Yubero, 2018). These results are a relevant to prevent the serious psycho-social consequences of CB found in high school graders (Kowalski et al., 2014), to promote their affective health.

CB prevention in elementary and middle school will help teachers prevent student's psychosocial problems (e.g. depression, anxiety) resulting from CB situations. Therefore, educators should try to integrate in their lessons pedagogical frameworks like cooperative learning (instead of creating competitive environments), which have been found positive to build social relations in school contexts suffering from CB (Hortigüela Alcalá et al., 2019). This type of interventions or programs have been found to improve individuals' prosocial skills and behaviors (DeSmet et al., 2018; Van Ryzin, Roseth, \& Biglan, 2020), classroom climates, sense of belonging and the victim's self-esteem, which, in turn, has an impact on the positive evolution of cybervictims (Aizenkot \& Kashy-Rosenbaum, 2020; Hortigüela et al., 2019). Additionally, teachers could be supported by psychologists, since they are key agents in the psychological assessment of the students (to identify psychosocial problems), as wells as in the design of interventions according to the students' needs (Diamanduros, Downs, \& Jenkins, 2008). All this can lead to better class participation and performance (Kowalski et al., 2014).

\subsection{Findings/conclusions on students' sociodemographic variables}

Several reported outcomes compared different socio-demographic variables such as gender (13 articles) and grade (7 articles), above all. Some studies showed that middle school girls observed more sexual harassment episodes (Machimbarrena \& Garaigordobil, 2018); exhibited more anxiety (Coelho \& Romão, 2018), had more suicidal thoughts/behaviors (Wang et al., 2018) or were more victimized (Delgado \& Escortell, 2018) than boys. On the other hand, middle school boys were more cybervictimized and involved in more bullying behaviors (Machimbarrena \& Garaigordobil, 2018), reported worst links with restrictive mediation or CV (Wright, 2017c) than girls. These results are in line with previous works at different school grades which reported that boys were involved in more bullying behaviors (Sun et al., 2016). However, another systematic review at older ages reported that girls were more cybervictimized than boys (Heiman \& Olenik-Shemesh, 2015), indicating that primary and middle school may be a key stage to raise awareness on CB regardless of gender.

These results have several implications for education. It is necessary to pay close attention to boys in upper grades of public elementary and middle schools, because they are more likely to become involved in $\mathrm{CB}$, as perpetrators and victims. Middle school girls seem to suffer more from CB, but an effective program could decrease CV and CB in these victims (Vivolo-Kantor et al., 2020). In any case, it is very important for parents and teachers to understand students' psychosocial well-being through psychosocial assessment or personal interviews; especially girls because they suffer more from CB (Coelho \& Romão, 2018; Wang et al., 2018). These assessments can be supported by mental health professionals working along with teachers to address CB scenarios and help students.

\subsection{Findings/conclusions on the connections between bullying and $C B$}

Online and face-to-face scenarios were assessed regarding students' feelings. Different bullying forms in middle school were mediated by social integration and low perception of negative relationships (Moyano et al., 2019) or the level of forgiveness related to mental health (Quintana-Orts \& Rey, 2018). Moreover, different victimization forms predicted suicidal thoughts and behaviors in middle school students (Wang et al., 2018), in concordance with results reported in higher students (Kowalski et al., 2014), and elicited feelings such as students' sadness or anger, being greater for victimization than CV (Wright, 2017a). Other studies concluded that CV could be related to victimization (Sidera et al., 2020). Elementary students who witnessed CB showed higher levels of anxiety than bullying witnesses (Doumas \& Midgett, 2020). Therefore, educators must provide students with opportunities to "open up" and tell them their worries and fears, as Cuesta et al. (2020) or DeSmet et al. (2018) showed, through the implementation of specific interventions facing and understanding $\mathrm{CB}$ situations.

Finally, Meter and Bauman (2018) reported that CB predicted victimization and bullying in both elementary and middle school students. Consequently, those studying specific cases of bullying should pay attention to possible situations of $\mathrm{CB}$, and vice versa. Previous systematic reviews conducted in different age groups also showed that there are strong relationships between bullying and $\mathrm{CB}$ (Zych et al., 2015).

\subsection{Findings/conclusions on students' roles related to $C B$}

The students' role in CB scenarios showed a great variety of outcomes. Firstly, Machimbarrena and Garaigordobil (2018) showed that all elementary and middle school students reported similar levels of pure-victim/bully and witness. The influence of CB roles could 
have an impact on social anxiety and students' withdrawal in middle school (Coelho \& Romão, 2018). CB emerged influenced by social reinforcement goals in cyberbullies and witnesses; and social self-concept and learning goals in middle school cybervictims (Delgado, Escortell, Martínez-Monteagudo, Ferrández-Ferrer, \& Sanmartín, 2019) who suffered behaviors such as blocking, deleting and changing passwords (Muller et al., 2017). These findings are consistent with the results of Romera, Cano, García-Fernández, and Ortega-Ruiz (2016), who reported that higher-grade bullies manifested the need to be socially recognized. So, educators should try to develop interpersonal and social skills such as empathy and assertiveness during the lessons in order to improve students' communication and relationships and thus prevent conflicts related to bullying or CB (Moyano et al., 2019).

According to the relation between the roles and bullying/CB, previous studies showed that traditional bullying and $\mathrm{CB}$ seem to be correlated (Görzig \& Machackova, 2015), including high school students too (Lozano-Blasco, Cortés-Pascual, \& Latorre-Martínez, 2020). In line with this idea, middle school students who perpetrated or suffered bullying were more likely to be involved in CB/CV (Athanasiades, Baldry, Kamariotis, Kostouli, \& Psalti, 2016), especially for bullies (Coelho \& Romão, 2018). Casas, del Rey \& Ortega-Ruiz (2013), consistent with this idea, informed that there are multiple relationships between predictive variables of bullying and specific variables that predict CB. However, Chu et al. (2018b) showed that bullies and victims maintained their roles in online and offline contexts but changed their roles in the other contexts (bullies suffered CB and vice versa). High school students also showed this trend (Lozano-Blasco et al., 2020), but traditional bullying seemed to decrease with age (not for CB) (Jenaro, Flores, \& Frías, 2018). These results indicate that it seems necessary to conduct more anti-bullying programs in middle school students than in high schoolers. Moreover, middle school CB tended to be more suffered, observed, and perpetrated than bullying (Machimbarrena \& Garaigordobil, 2017). These results support the idea that CB strengthened moral disengagement and weakened responsibility and self-efficacy more than bullying (Knauf et al., 2018). Therefore, pedagogical frameworks like Teaching for Personal and Social Responsibility, which was created to improve responsibility on students at risk (Hellison, 2011), can help students develop responsibility preventing behavior conflicts and violence. In this sense, while Romero-Abrio, León-Moreno, Musitu-Ferrer, and Villarreal-González (2019) found that academic self-concept was related with CV in higher school grades, Escortell, Delgado, and Martínez-Monteagudo (2020) found a direct and negative relationship between CV and self-concept in middle school (10-12-year-old). Going deeper into this school stage (10-13-year-old), Escortell, Aparisi, et al. (2020) confirmed that the extraversion trait is an explanatory factor for being a victim and openness is a protective factor against being a cyberbully. Agreeableness was found to be a positive predictor of being a cyberbullying victim. Thus, the explanatory factors for being a victim and a victimized bully were verbal aggression and anger. Therefore, educators should try to promote openness and decrease aggressiveness in their classes. For example, programs describing bullying/CB situations and their consequences in different roles (victim, aggressor or bystander) can help students express feelings and improve their behaviors in response to them (e.g., Garaigordobil \& Martínez-Valderrey, 2016).

Consistent with the previous subsection, $\mathrm{CB}$ and bullying roles seem to be related, although it is not clear if the students maintain their roles in and out of the online contexts. Teachers and parents of elementary and middle school graders should pay attention to any bullying situation and find if there is a CB scenario connected to it to address both (Meter \& Bauman, 2018; Zych, 2015).

\subsection{Findings/conclusions on external factors and students' responses}

One supportive element to prevent CB is the influence of external factors such as parents' mediation or teachers' interventions. Middle school parental mediation reported contradictory outcomes: parental mediation reduced CB perpetration (Wright, 2017c) and positively impacted students' depression (Wright, 2016; 2017b) or suicidal thoughts/behaviors (Wang et al., 2018), while other studies showed that an authoritarian parental style (Govender \& Young, 2018) and their monitoring (Meter \& Bauman, 2018) negatively affected CB. The reason could be that parental influence decreases in early adolescence (Sasson \& Mesch, 2017). Teacher interventions reported better results, showing that they were an effective support to decrease CB (Wright, 2017b) along with peers' mediation (Wright, 2016; 2017c). Similar results were found in Elsaesser, Russell, Ohannessian \& Patton's (2017) review including high school graders, reinforcing the idea that parental mediation could provide emotional warmth to support students' disengagement from online activities.

Parental and teacher interventions and peers' mediation could be considered protective factors and key elements in the prevention and fight against CB (e.g., to accept bullying; Carter, van der Watt, \& Esterhuyse, 2020). On the one hand, teachers and parents organized efforts against CB appear to be a feasible way to reduce it. Nevertheless, an authoritarian parental style and student monitoring should not take place in middle school contexts, because they could have a negative effect on CB, making it worse. On the other hand, tasks and interventions reinforcing social support among groupmates can generate positive relations, prosocial behaviors, and interpersonal skills (DeSmet et al., 2018; Van Ryzin et al., 2020), which can help decrease CB.

\subsection{Findings/conclusions on effectiveness of $C B$ programs}

Related to teachers and other students' influence, a potential solution to prevent or improve $\mathrm{CB} / \mathrm{CV}$ scenarios could be the implementation of school programs (Da Silva et al., 2016). Previous systematic reviews (e.g., Couvillon \& Ilieva, 2011; Gaffney et al., 2019) also suggested that $\mathrm{CB}$ intervention and prevention programs were effective. Moreover, the ViSC program reported positive effects in other school levels, although it was particularly effective in lower grades such as middle school (Solomontos-Kountouri, Gradinger, Yanagida, \& Strohmeier, 2016). Therefore, improvements in these scenarios could support safe class climates (Aizenkot and Kashy-Rosenbaum, 2018, 2020). Moreover, positive class climates could prevent CV even out of the school context in both elementary and middle school students (Holfeld \& Leadbeater, 2017), because the students could reduce violent and aggressive behaviors (Garaigordobil \& Martínez-Valderrey, 2016) and increase their intention to be a positive witness, thus improving their quality of life 
(DeSmet et al., 2018). Future studies should assess the effectiveness of these programs at older ages where other programs have reported similar results in relation to their effectiveness to prevent CB, such as No Trap (Palladino, Nocentini, \& Menesini, 2016)! or ConRed (Ortega-Ruiz, Rey, \& Casas, 2012). Anyway, the positive influence of programs on the CB prevention at early ages (Gaffney et al., 2019) highlight that they can help to avoid these types of aggressions, when students begin to use electronic devices and social media.

CB programs have been found useful for the prevention and reduction of CB in elementary and middle school students. Schools and teachers could use scientifically sound programs such as ViSC (Solomontos-Kountouri et al., 2016; Gradinger et al. (2016), Cyberprogram 2.0 (Garaigordobil \& Martínez-Valderrey, 2016) or Dating Matters (Vivolo-Kantor et al., 2020) to prevent and reduce CB and students' permanence in CB behaviors. In this sense, it is essential to teach conflict resolution skills and develop students' empowerment (Cuesta et al., 2020). Additionally, teachers should promote a positive class climate as protective factor to prevent CV, even out of the school context.

\section{Conclusions}

In conclusion, several reviews on $\mathrm{CB}$ including middle and high school students have been conducted, but there are no previous reviewes on $\mathrm{CB}$ including elementary and middle school students specifically. Students at these ages begin to socialize with their equals and to have access to technology and, consequently, to be at risk of CB. Studies conducted on these ages have reported similar results to previous reviews including middle and high school students: influence of CB/CV on psycho-social variables such as depression or anxiety, strong links between $\mathrm{CB}$ and bulling scenarios, roles of $\mathrm{CB}$ and their links to bullying, influence of external factors or programs to prevent $\mathrm{CB}$, and socio-demographic variables such as gender or school type. However, some attitudes varied from older samples based on students' gender/age, and similar CB programs were not found in adolescents. Elementary/middle school teachers or educators should take CB into account to prevent potential risks and guarantee students' psycho-social health and avoid future CB conflicts. Moreover, the links between bullying and CB could help to transfer the benefits of these programs between both contexts. Protective factors, such as specific pedagogical approaches (e.g., Cooperative Learning or Teaching for Personal and Social Responsibility) or programs, as well as the joined work of different agents (e.g. psychologists, teachers, parents, peers), should be considered to promote a positive evolution on CB prevention. Finally, this review shows a lack of qualitative studies to report results on the students' perceptions of CB scenarios, which could improve the quality of the conclusions on this topic. More research on this theme is needed from short-age students to consolidate positive social behaviors.

\section{Funding source declaration}

There is no funding.

\section{Submission declaration and verification}

All authors have seen and approved the final version of the manuscript. This manuscript has not received prior publication and is not under consideration for publication elsewhere.

\section{Permission note}

There are no figures, tables or appendix in this article that are not original content and therefore no permissions are warranted.

\section{Author contributions}

Carlos Evangelio: Conceptualization; Data curation; Methodology; Project administration; Resources; Supervision; original draft; review \& editing; Validation; Visualization. Pablo Rodríguez-González: Conceptualization; Data curation; Methodology; Project administration; Resources; Supervision; original draft; review \& editing; Validation; Visualization. Javier Fernández-Río: Conceptualization; Data curation; Methodology; Project administration; Supervision; original draft; review \& editing; Validation; Visualization. Sixto González-Víllora: Conceptualization; Data curation; Methodology; Project administration; Supervision; original draft; review \& editing; Validation; Visualization.

\section{Declaration of competing interest}

The authors declare that no competing interests exist and there is no financial interest or belief that could have affected our objectivity.

\section{References}

Aizenkot, D. (2017). WhatsApp cyberbullying among children and adolescents in Israel: A pilot research. Educational Counseling, $20,363-389$.

Aizenkot, D., \& Kashy-Rosenbaum, G. (2018). Cyberbullying in WhatsApp classmates' groups: Evaluation of an intervention program implemented in Israeli elementary and middle schools. New Media \& Society, 20(12), 4709-4727. https://doi.org/10.1177/1461444818782702 
Aizenkot, D., \& Kashy-Rosenbaum, G. (2020). The effectiveness of Safe surfing intervention program in reducing WhatsApp cyberbullying and improving classroom climate and student sense of class belonging in elementary school. The Journal of Early Adolescence, 1-17. https://doi.org/10.1177/0272431620931203

Athanasiades, C., Baldry, A. C., Kamariotis, T., Kostouli, M., \& Psalti, A. (2016). The "net" of the internet: Risk factors for cyberbullying among secondary-school students in Greece. European Journal on Criminal Policy and Research, 22(2), 301-317. https://doi.org/10.1007/s10610-016-9303-4

Braun, V., \& Clarke, V. (2006). Using thematic analysis in psychology. Qualitative Research in Psychology, 3(2), 77-101. https://doi.org/10.1191/1478088706qp063oa

Calvete, E., Orue, I., \& Gámez-Guadix, M. (2016). Cyberbullying victimization and depression in adolescents: The mediating role of body image and cognitive schemas in a one-year prospective study. European Journal on Criminal Policy and Research, 22, 271-284. https://doi.org/10.1007/s10610-015-9292-8

Camerini, A. L., Marciano, L., Carrara, A., \& Schulz, P. J. (2020). Cyberbullying perpetration and victimization among children and adolescents: A systematic review of longitudinal studies. Telematics and Informatics. https://doi.org/10.1016/j.tele.2020.101362

Cañas, E., Estévez, E., Marzo, J. C., \& Piqueras, J. A. (2019). Psychological adjustment in cybervictims and cyberbullies in secondary education. Anales de Psicología/ Annals of Psychology, 35(3), 434-443. https://doi.org/10.6018/analesps.35.3.323151

Carter, M., van der Watt, R., \& Esterhuyse, K. (2020). The relationship between perceived parenting dimensions, attachment, and pre-adolescent bullying. Journal of Psychology in Africa, 30(2), 106-118. https://doi.org/10.1080/14330237.2020.1744280

Casas, J. A., del Rey, R., \& Ortega-Ruiz, R. (2013). Bullying and cyberbullying: Convergent and divergent predictor variables. Computers in Human Behavior, 29(3), 580-587. https://doi.org/10.1016/j.chb.2012.11.015

Chu, X. W., Fan, C. Y., Liu, Q. Q., \& Zhou, Z. K. (2018a). Cyberbullying victimization and symptoms of depression and anxiety among Chinese adolescents: Examining hopelessness as a mediator and self-compassion as a moderator. Computers in Human Behavior, 86, 377-386. https://doi.org/10.1016/j.chb.2018.04.039

Chu, X. W., Fan, C. Y., Liu, Q. Q., \& Zhou, Z. K. (2018b). Stability and change of bullying roles in the traditional and virtual contexts: A three-wave longitudinal study in Chinese early adolescents. Journal of Youth and Adolescence, 47(11), 2384-2400. https://doi.org/10.1007/s10964-018-0908-4

Coelho, V. A., \& Romão, A. M. (2018). The relation between social anxiety, social withdrawal and (cyber) bullying roles: A multilevel analysis. Computers in Human Behavior, 86, 218-226. https://doi.org/10.1016/j.chb.2018.04.048

Cole, D. A., Zelkowitz, R. L., Nick, E., Martin, N. C., Roeder, K. M., Sinclair-McBride, K., et al. (2016). Longitudinal and incremental relation of cybervictimization to negative self-cognitions and depressive symptoms in young adolescents. Journal of Abnormal Child Psychology, 44(7), 1321-1332. https://doi.org/10.1007/ s10802-015-0123-7

Couvillon, M. A., \& Ilieva, V. (2011). Recommended practices: A review of schoolwide preventative programs and strategies on cyberbullying. Preventing School Failure: Alternative Education for Children and Youth, 55(2), 96-101. https://doi.org/10.1080/1045988X.2011.539461

Creswell, J., \& Miller, D. (2000). Determining validity in qualitative inquiry. Theory into Practice, 39(3), 124-130. https://doi.org/10.1207/s15430421tip3903_2

Cuesta, L., Hennig, C., Duque, L. A., \& Malfasi, S. (2020). Cyberbullying: Tackling the silent enemy. International Journal of Inclusive Education, 24(9), 936-947. https://doi.org/10.1080/13603116.2018.1500648

Da Silva, J. L., De Oliveira, W. A., Braga, I. F., Farias, M. S., da Silva, E. A., Gonçalves, M. F. C., ... Silva, M. A. I. (2016). The effects of a skill-based intervention for victims of bullying in Brazil. International Journal of Environmental Research and Public Health, 13(11), 1042. https://doi.org/10.3390/ijerph13111042

Delgado, B., \& Escortell, R. (2018). Sex and grade differences in cyberbullying of Spanish students of 5th and 6th grade of Primary Education. Annals of psychology, 34 (3). https://doi.org/10.6018/analesps.34.3.283871, 472-48.

Delgado, B., Escortell, R., Martínez-Monteagudo, M. C., Ferrández-Ferrer, A., \& Sanmartín, R. (2019). Cyberbullying, self-concept and academic goals in childhood. Spanish Journal of Psychology, 22(e46), 1-10. https://doi.org/10.1017/sjp.2019.46

Dennehy, R., Meaney, S., Walsh, K. A., Sinnott, C., Cronin, M., \& Arensman, E. (2020). Young people's conceptualizations of the nature of cyberbullying: A systematic review and synthesis of qualitative research. Aggression and Violent Behavior, 51, 101379. https://doi.org/10.1016/j.avb.2020.101379

DeSmet, A., Bastiaensens, S., Van Cleemput, K., Poels, K., Vandebosch, H., Deboutte, G., et al. (2018). The efficacy of the friendly attac serious digital game to promote prosocial bystander behavior in cyberbullying among young adolescents: A cluster-randomized controlled trial. Computers in Human Behavior, 78, 336-347. https://doi.org/10.1016/j.chb.2017.10.011

DeSmet, A., De Bourdeaudhuij, I., Walrave, M., \& Vandebosch, H. (2019). Associations between bystander reactions to cyberbullying and victims' emotional experiences and mental health. Cyberpsychology, Behavior, and Social Networking, 22, 10. https://doi.org/10.1089/cyber.2019.0031

Diamanduros, T., Downs, E., \& Jenkins, S. J. (2008). The role of school psychologists in the assessment, prevention, and intervention of cyberbullying. Psychology in the Schools, 45(8), 693-704. https://doi.org/10.1002/pits.20335

Díaz, K. I., \& Fite, P. J. (2019). Cyber victimization and its association with substance use, anxiety, and depression symptoms among middle school youth. Child and Youth Care Forum, 48(4), 529-544. https://doi.org/10.1007/s10566-019-09493-w

Doumas, D. M., \& Midgett, A. (2020). The association between witnessing cyberbullying and depressive symptoms and social anxiety among elementary school students. Psychology in the Schools, 1-16. https://doi.org/10.1002/pits.22467

Ellison, N. B., Steinfield, C., \& Lampe, C. (2007). The benefits of facebook “friends:” Social capital and college students' use of online social network sites. Journal of Computer-Mediated Communication, 12(4), 1143-1168. https://doi.org/10.1111/j.1083-6101.2007.00367.x

Elsaesser, C., Russell, B., Ohannessian, C. M., \& Patton, D. (2017). Parenting in a digital age: A review of parents' role in preventing adolescent cyberbullying. Aggression and Violent Behavior, 35, 62-72. https://doi.org/10.1016/j.avb.2017.06.004

Escortell, R., Aparisi, D., Martínez-Monteagudo, M. C., \& Delgado, B. (2020). Personality traits and aggression as explanatory variables of cyberbullying in Spanish preadolescents. International Journal of Environmental Research and Public Health, 17(16), 5705. https://doi.org/10.3390/ijerph17165705

Escortell, R., Delgado, B., \& Martínez-Monteagudo, M. C. (2020). Cybervictimization, self-concept, aggressiveness, and school anxiety in school children: A structural equations analysis. International Journal of Environmental Research and Public Health, 17(19), 7000. https://doi.org/10.3390/ijerph17197000

Fahy, A. E., Stansfeld, S. A., Smuk, M., Smith, N. R., Cummins, S., \& Clark, C. (2016). Longitudinal associations between cyberbullying involvement and adolescent mental health. Journal of Adolescent Health, 59(5), 502-509. https://doi.org/10.1016/j.jadohealth.2016.06.006

Fletcher, A., Fitzgerald-Yau, N., Jones, R., Allen, E., Viner, R. M., \& Bonell, C. (2014). Brief report: Cyberbullying perpetration and its associations with sociodemographics, aggressive behaviour at school, and mental health outcomes. Journal of Adolescence, 37(8), 1393-1398. https://doi.org/10.1016/j. adolescence.2014.10.005

Gaffney, H., Farrington, D. P., Espelage, D. L., \& Ttofi, M. M. (2019). Are cyberbullying intervention and prevention programs effective? A systematic and metaanalytical review. Aggression and Violent Behavior, 45, 134-153. https://doi.org/10.1016/j.avb.2018.07.002

Garaigordobil, M. (2013). Cyberbullying. Screening for peer bullying. Madrid, Spain: TEA Ediciones.

Garaigordobil, M. (2015). Cyberbullying in adolescents and youth in the Basque Country: Changes with age. Anales de Psicología, 31(3), 1069-1076. https://doi.org/ 10.6018/analesps.31.3.179151

Garaigordobil, M., \& Machimbarrena, J. M. (2019). Victimization and perpetration of bullying/cyberbullying: Connections with emotional and behavioral problems and childhood stress. Psychosocial Intervention, 28, 67-73. https://doi.org/10.5093/pi2019a3

Garaigordobil, M., \& Martínez-Valderrey, V. (2016). Impact of Cyberprogram 2.0 on different types of school violence and aggressiveness. Frontiers in Psychology, 7 (428). https://doi.org/10.3389/fpsyg.2016.00428

Görzig, A., \& Machackova, H. (2015). Cyberbullying from a socio-ecological perspective: A contemporary synthesis of findings from EU kids online. LSE Department of Media and Communications. https://repository.uwl.ac.uk/id/eprint/1448/.

Govender, C., \& Young, K. (2018). A comparison of gender, age, grade, and experiences of authoritarian parenting amongst traditional and cyberbullying perpetrators. South African Journal of Education, 38(1), S1-S11. https://doi.org/10.15700/saje.v38ns1a1519

Gradinger, P., Yanagida, T., Strohmeier, D., \& Spiel, C. (2016). Effectiveness and sustainability of the ViSC Social Competence Program to prevent cyberbullying and cyber-victimization: Class and individual level moderators. Aggressive Behavior, 42(2), 181-193. https://doi.org/10.1002/ab.21631

Hamm, M. P., Newton, A. S., Chisholm, A., Shulhan, J., Milne, A., Sundar, P., et al. (2015). Prevalence and effect of cyberbullying on children and young people: A scoping review of social media studies. JAMA Pediatrics, 169(8), 770-777. https://doi.org/10.1001/jamapediatrics.2015.0944 
Heerde, J. A., \& Hemphill, S. A. (2018). Examination of associations between informal help-seeking behavior, social support, and adolescent psychosocial outcomes: A meta-analysis. Developmental Review, 47, 44-62. https://doi.org/10.1016/j.dr.2017.10.001

Heiman, T., \& Olenik-Shemesh, D. (2015). Cyberbullying experience and gender differences among adolescents in different educational settings. Journal of Learning Disabilities, 48(2), 146-155. https://doi.org/10.1177/0022219413492855

Hellison, D. R. (2011). Teaching responsibility through physical activity ( ${ }^{\text {rd }}$ ed.). Champaign, Il: Human Kinetics.

Hemingway, P., \& Brereton, N. (2009). What is a systematic review? (2nd ed.). London: Hayward Medical Communications. Retrieved from http://www.medicine.ox. ac.uk/bandolier/painres/download/whatis/syst-review.pdf.

Holfeld, B., \& Leadbeater, B. J. (2015). The nature and frequency of cyber bullying behaviors and victimization experiences in young Canadian children. Canadian Journal of School Psychology, 30(2), 116-135. https://doi.org/10.1177/0829573514556853

Holfeld, B., \& Leadbeater, B. J. (2017). Concurrent and longitudinal associations between early adolescents' experiences of school climate and cyber victimization. Computers in Human Behavior, 76, 321-328. https://doi.org/10.1016/j.chb.2017.07.037

Hong, Q. N., Fàbregues, S., Bartlett, G., Boardman, F., Cargo, M., Dagenais, P., et al. (2018). The mixed methods appraisal tool (MMAT) version 2018 for information professionals and researchers. Education for Information, 34(4), 285-291. https://doi.org/10.3233/EFI-180221

Hortigüela Alcalá, D., Fernández Río, J., González Calvo, G., \& Pérez Pueyo, Á. (2019). Effects of a cooperative learning intervention program on cyberbullying in secondary education: A case study. Qualitative Report, 24(10), 2426-2440. https://doi.org/10.46743/2160-3715/2019.3862

Hülür, G., \& Macdonald, B. (2020). Rethinking social relationships in old age: Digitalization and the social lives of older adults. American Psychologist, 75(4), 554-566. https://doi.org/10.1037/amp0000604

Jadambaa, A., Thomas, H. J., Scott, J. G., Graves, N., Brain, D., \& Pacella, R. (2019). Prevalence of traditional bullying and cyberbullying among children and adolescents in Australia: A systematic review and meta-analysis. Australian and New Zealand Journal of Psychiatry, 53(9), 878-888. https://doi.org/10.1177/ 0004867419846393

Jenaro, C., Flores, N., \& Frías, C. P. (2018). Systematic review of empirical studies on cyberbullying in adults: What we know and what we should investigate. Aggression and Violent Behavior, 38, 113-122. https://doi.org/10.1016/j.avb.2017.12.003

Knauf, R. K., Eschenbeck, H., \& Hock, M. (2018). Bystanders of bullying: Social-cognitive and affective reactions to school bullying and cyberbullying. Cyberpsychology. Journal of Psychosocial Research on Cyberspace, 12(4). https://doi.org/10.5817/CP2018-4-3. article 3.

Kowalski, R. M., Giumetti, G. W., Schroeder, A. N., \& Lattanner, M. R. (2014). Bullying in the digital age: A critical review and meta-analysis of cyberbullying research among youth. Psychological Bulletin, 4, 1073-1137. https://doi.org/10.1037/a0035618

Kowalski, R. M., Limber, S. P., \& McCord, A. (2019). A developmental approach to cyberbullying: Prevalence and protective factors. Aggression and Violent Behavior, 45, 20-32. https://doi.org/10.1016/j.avb.2018.02.009

Longobardi, C., Gullotta, G., Ferrigno, S., Jungert, T., Thornberg, R., \& Settanni, M. (2020). Cyberbullying and cybervictimization among preadolescents: Does time perspective matter? Scandinavian Journal of Psychology, 62(2), 259-266. https://doi.org/10.1111/sjop.12686

López-Pradas, I. C., Romera, E. M., Casas, J. A., \& Ortega-Ruiz, R. (2017). Cybergossip and cyberbullying during primary school years. Psicologia Educativa, 23(2), 73-80. https://doi.org/10.1016/j.pse.2017.05.007

Lozano-Blasco, R., Cortés-Pascual, A., \& Latorre-Martínez, P. (2020). Being a cybervictim and a cyberbully - the duality of cyberbullying: A meta-analysis. Computers in Human Behavior. https://doi.org/10.1016/j.chb.2020.106444

Machimbarrena, J. M., \& Garaigordobil, M. (2017). Bullying/cyberbullying in 5th and 6th grade: Differences between public and private schools. Anales de Psicología, 33(2), 319-326. https://doi.org/10.6018/analesps.33.2.249381

Machimbarrena, J. M., \& Garaigordobil, M. (2018). Prevalence of bullying and cyberbullying in the last stage of primary education in the Basque Country. Spanish Journal of Psychology, 21, e48. https://doi.org/10.1017/sjp.2018.41

Martínez-Monteagudo, M. C., Delgado, B., Díaz-Herrero, Á., \& García-Fernández, J. M. (2020). Relationship between suicidal thinking, anxiety, depression and stress in university students who are victims of cyberbullying. Psychiatry Research, 286(2020), 112856. https://doi.org/10.1016/j.psychres.2020.112856

Menesini, E., Nocentini, A., Palladino, B. E., Frisén, A., Berne, S., Ortega-Ruiz, R., et al. (2012). Cyberbullying definition among adolescents: A comparison across six European countries. Cyberpsychology, Behavior, and Social Networking, 15(9), 455-463. https://doi.org/10.1089/cyber.2012.0040

Meter, D. J., \& Bauman, S. (2018). Moral disengagement about cyberbullying and parental monitoring. Effects on traditional bullying and victimization via cyberbullying involvement. The Journal of Early Adolescence, 38(3), 303-326. https://doi.org/10.1177/0272431616670752

Mishna, F. (2004). A qualitative study of bullying from multiple perspectives. Children and Schools, 26(4), 234-247. https://doi.org/10.1093/cs/26.4.234

Moher, D., Liberati, A., Tetzlaff, J., Altman, D. G., \& The PRISMA Group. (2009). Preferred reporting items for systematic reviews and meta-analyses: The PRISMA statement. PLoS Medicine, 6(7), e1000097. https://doi.org/10.1371/journal.pmed.1000097

Moyano, N., Ayllón, E., Antoñanzas, J. L., \& Cano, J. (2019). Children's social integration and low perception of negative relationships as protectors against bullying and cyberbullying. Frontiers in Psychology, 10, 643. https://doi.org/10.3389/fpsyg.2019.00643

Muller, R. D., Skues, J. L., \& Wise, L. Z. (2017). Cyberbullying in Australian primary schools: How victims differ in attachment, locus of control, self-esteem, and coping styles compared to non-victims. Journal of psychologists and counsellors in schools, 27(1), 85-104. https://doi.org/10.1017/jgc.2016.5

Myers, C. A., \& Cowie, H. (2019). Cyberbullying across the lifespan of education: Issues and interventions from school to university. International Journal of Environmental Research and Public Health, 16(7), 1217. https://doi.org/10.3390/ijerph16071217

National Statistics Institute. (2019). Encuesta sobre Equipamiento y Uso de Tecnologías de Información y Comunicación en los Hogares [Survey on Equipment and Use of Information and Communication Technologies in Homes] https://ine.es/prensa/tich_2019.pdf.

Navarro, R., Larrañaga, E., \& Yubero, S. (2018). Differences between preadolescent victims and non-victims of cyberbullying in cyber-relationship motives and coping strategies for handling problems with peers. Current Psychology, 37(1), 116-127. https://doi.org/10.1007/s12144-016-9495-2

Nocentini, A., Calmaestra, J., Schultze-Krumbholz, A., Scheithauer, H., Ortega, R., \& Menesini, E. (2010). Cyberbullying: Labels, behaviours and definition in three European countries. Australian Journal of Guidance and Counselling, 20(2), 129-142. https://doi.org/10.1375/ajgc.20.2.129

Oakley, A. (2012). Foreword. In D. Gough, S. Oliver, \& J. Thomas (Eds.), An introduction to systematic reviews (pp. 6-10). London: SAGE Publications.

Ofcom. (2017). Children and parents: Media use and attitudes report. London: Office of Communications London.

Olweus, D. (1997). Bully/victim problems in school: Facts and intervention. European. Journal of Psychology and Education, 12(4), 495-510. https://doi.org/10.1007/ bf03172807

Ortega-Ruiz, R., Rey, R. D., \& Casas, J. A. (2012). Knowing, building and living together on internet and social networks: The ConRed cyberbullying prevention program. International Journal of Computer Vision, 6(2), 302-312. https://hdl.handle.net/11441/73655.

Pabian, S., \& Vandebosch, H. (2016). An investigation of short-term longitudinal associations between social anxiety and victimization and perpetration of traditional bullying and cyberbullying. Journal of Youth and Adolescence, 45(2), 328-339. https://doi.org/10.1007/s10964-015-0259-3

Palermiti, A. L., Servidio, R., Bartolo, M. G., \& Costabile, A. (2017). Cyberbullying and self-esteem: An Italian study. Computers in Human Behavior, 69, $136-141$. https://doi.org/10.1016/j.chb.2016.12

Palladino, B. E., Nocentini, A., \& Menesini, E. (2016). Evidence-based intervention against bullying and cyberbullying: Evaluation of the NoTrap! program in two independent trials. Aggressive Behavior, 42(2), 194-206. https://doi.org/10.1002/ab.21636

Patchin, J. W., \& Hinduja, S. (2010). Cyberbullying and self-esteem. Journal of School Health, 80, 614-621. https://doi.org/10.1111/j.1746-1561.2010.00548.x

Patchin, J. W., \& Hinduja, S. (2015). Measuring cyberbullying: Implications for research. Aggression and Violent Behavior, 23, 69-74. https://doi.org/10.1016/j. avb.2015.05.013

Peter, I. K., \& Petermann, F. (2018). Cyberbullying: A concept analysis of defining attributes and additional influencing factors. Computers in Human Behavior, 86, 350-366. https://doi.org/10.1016/j.chb.2018.05.013

Pew Research Center. (2018). Teens. Social Media \& Technology. http://www.pewinternet.org/2018/05/31/teens-social-media-tech-nology-2018/.

Quintana-Orts, C., \& Rey, L. (2018). Traditional bullying, cyberbullying and mental health in early adolescents: Forgiveness as a protective factor of peer victimization. International Journal of Environmental Research and Public Health, 15(11), 2389. https://doi.org/10.3390/ijerph15112389 
Romera, E., Cano, J., García-Fernández, C., \& Ortega-Ruiz, R. (2016). Cyberbullying: Social competence, motivation and peer relationships. Comunicar, 48, 71-79. https://doi.org/10.3916/C48-2016-07

Romero-Abrio, A., León-Moreno, C., Musitu-Ferrer, D., \& Villarreal-González, M. E. (2019). Family functioning, self-concept and cybervictimization: An analysis based on gender. Social Sciences, 8(69). https://doi.org/10.3390/socsci8020069

Sasson, H., \& Mesch, G. (2017). The role of parental mediation and peer norms on the likelihood of cyberbullying. The Journal of Genetic Psychology, $178(1)$, 15-27. https://doi.org/10.1080/00221325.2016.1195330

Schultze-Krumbholz, A., Hess, M., Pfetsch, J., \& Scheithauer, H. (2018). Who is involved in cyberbullying? Latent class analysis of cyberbullying roles and their associations with aggression, self-esteem, and empathy. Cyberpsychology: Journal of Psychosocial Research on Cyberspace, 12(4). https://doi.org/10.5817/CP20184-2. Article 2.

Sidera, F., Serrat, E., Collell, J., Perpiñà, G., Ortiz, R., \& Rostan, C. (2020). Bullying in primary school children: The relationship between victimization and perception of being a victim. International Journal of Environmental Research and Public Health, 17(24), 9540. https://doi.org/10.3390/ijerph17249540

Smith, P. K., \& Slonje, R. (2010). Cyberbullying: The Nature and Extent of a new kind of bullying. In S. Jimerson, S. Swearer, \& D. Espelage (Eds.), The international handbook of school bullyingAnd out of school (pp. 249-262). Routledge.

Solomontos-Kountouri, O., Gradinger, P., Yanagida, T., \& Strohmeier, D. (2016). The implementation and evaluation of the ViSC program in Cyprus: Challenges of cross-national dissemination and evaluation results. European Journal of Developmental Psychology, 13(6), 737-755. https://doi.org/10.1080/ 17405629.2015 .1136618

Sun, S., Fan, X., \& Du, J. (2016). Cyberbullying perpetration: A meta-analysis of gender differences. International Journal of Internet Science, 11 (1), 61-81.

Tanrikulu, I. (2018). Cyberbullying prevention and intervention programs in schools: A systematic review. School Psychology International, 39(1), 74-91. https://doi. org/10.1177/0143034317745721

Tokunaga, R. S. (2010). Following you home from school: A critical review and synthesis of research on cyberbullying victimization. Computers in Human Behavior, 26, 277-287. https://doi.org/10.1016/j.chb.2009.11.014

Torres, C. E., D'Alessio, S. J., \& Stolzenberg, L. (2020). The effect of social, verbal, physical, and cyberbullying victimization on academic performance. Victims and Offenders, 15(1), 1-21. https://doi.org/10.1080/15564886.2019.1681571

Van Ryzin, M. J., Roseth, C. J., \& Biglan, A. (2020). Mediators of effects of cooperative learning on prosocial behavior in middle school. International journal of applied positive psychology, 5(1), 37-52. https://doi.org/10.1007/s41042-020-00026-8

Varghese, M. E., \& Pistole, M. C. (2017). College student cyberbullying: Self-esteem, depression, loneliness, and attachment. Journal of College Counseling, $20,7-21$. https://doi.org/10.1002/jocc. 12055

Vivolo-Kantor, A. M., Niolon, P. H., Estefan, L. F., Le, V. D., Tracy, A. J., Latzman, N. E., et al. (2020). Middle school effects of the dating Matters ${ }^{\circledR}$ comprehensive teen dating violence prevention model on physical violence, bullying, and cyberbullying: A cluster-randomized controlled trial. Prevention Science, 1-11. https://doi. org/10.1007/s11121-019-01071-9

Wachs, S., Vazsonyi, A. T., Wright, M. F., \& Ksinan Jiskrova, G. (2020). Cross-National associations among cyberbullying victimization, self-esteem, and internet addiction: Direct and indirect effects of alexithymia. Frontiers in Psychology, 11, 1368. https://doi.org/10.3389/fpsyg.2020.01368

Wang, C., La Salle, T., Wu, C., Do, K. A., \& Sullivan, K. E. (2018). School climate and parental involvement buffer the risk of peer victimization on suicidal thoughts and behaviors among Asian American middle school students. Asian American journal of psychology, 9(4), 296-307. https://doi.org/10.1037/aap0000138

Wang, W., Xie, X., Wang, X., Lei, L., Hu, Q., \& Jiang, S. (2019). Cyberbullying and depression among Chinese college students: A moderated mediation model of social anxiety and neuroticism. Journal of Affective Disorders, 256, 54-61. https://doi.org/10.1016/j.jad.2019.05.061

Wegge, D., Vandebosch, H., Eggermont, S., \& Pabian, S. (2016). Popularity through online harm: The longitudinal associations between cyberbullying and sociometric status in early adolescence. The Journal of Early Adolescence, 36(1), 86-107. https://doi.org/10.1177/0272431614556351

Wright, M. F. (2017a). Adolescents' emotional distress and attributions for face-to-face and cyber victimization: Longitudinal linkages to later aggression. Journal of Applied Developmental Psychology, 48, 1-13. https://doi.org/10.1016/j.appdev.2016.11.002

Wright, M. F. (2017b). Cyber victimization and depression among adolescents with intellectual disabilities and developmental disorders: The moderation of perceived social support. Journal of Mental Health Research in Intellectual Disabilities, 10(2), 126-143. https://doi.org/10.1080/19315864.2016.1271486

Wright, M. F. (2017c). Parental mediation, cyberbullying, and cybertrolling: The role of gender. Computers in Human Behavior, 71, 189-195. https://doi.org/10.1016/ j.chb.2017.01.059

Wright, M. F., \& Li, Y. (2013). The association between cyber victimization and subsequent cyber aggression: The moderating effect of peer rejection. Journal of Youth and Adolescence, 42, 662-674. https://doi.org/10.1007/s10964-012-9903-3

Wright, M. F., \& Wachs, S. (2019). Adolescents' psychological consequences and cyber victimization: The moderation of school-belongingness and ethnicity. International Journal of Environmental Research and Public Health, 16(14), 2493. https://doi.org/10.3390/ijerph16142493

Wright, M. F., \& Wachs, S. (2020). Adolescents' cyber victimization: The influence of technologies, gender, and gender stereotype traits. International Journal of Environmental Research and Public Health, 17(4), 1293. https://doi.org/10.3390/ijerph17041293

Wright, M. F., Wachs, S., \& Harper, B. D. (2018). The moderation of empathy in the longitudinal association between witnessing cyberbullying, depression, and anxiety. Cyberpsychology: Journal of Psychosocial Research on Cyberspace, 12(4). https://doi.org/10.5817/CP2018-4-6. Article 6.

Zhang, D., Huebner, E. S., \& Tian, L. (2020). Neuroticism and cyberbullying among elementary school students: A latent growth curve modeling approach. Personality and Individual Differences, 171, 110472. https://doi.org/10.1016/j.paid.2020.110472

Zych, I., Ortega-Ruiz, R., \& Del Rey, R. (2015). Systematic review of theoretical studies on bullying and cyberbullying: Facts, knowledge, prevention and intervention. Aggression and Violent Behavior, 23, 1-21. https://doi.org/10.1016/j.avb.2015.10.001

Zych, I., Ortega-Ruiz, R., \& Marín-López, I. (2016). Cyberbullying: A systematic review of research, its prevalence and assessment issues in Spanish studies. Psicologia Educativa, 22(1), 5-18. https://doi.org/10.1016/j.pse.2016.03.002 